\title{
Intellectual Structure Of Ongoing Studies on Business Schools
}

\author{
Isabel Cristina Scafuto ${ }^{1}$ \\ isabelscafuto@gmail.com | (100000-0002-6788-3325 \\ Fernando Serra ${ }^{1}$ \\ fernandorserra@gmail.com | @0000-0002-8178-7313 \\ Luiz Guerrazzi ${ }^{1}$ \\ luizguerrazzi@gmail.com | @0000-0002-7100-5314 \\ Emerson Maccari ${ }^{1}$ \\ emersonmaccari@gmail.com | @0000-0001-7085-224X
}

\begin{abstract}
We examined the extant research on Business Schools (B-Schools) in an attempt to understand the intellectual structural influences in mainstream research, as well as the evolution and trends in research. Through a bibliometric study of co-citation and bibliographic coupling, supported by factor and network analyses of a sample of 493 articles, we examined 76 selected articles and their references. The results indicate that critiques of B-Schools influenced mainstream works. We found three primary sources of criticism at the intellectual level: Theory and Practice Gap, Social Relevance, and Curricula and Practice. The mainstream works identified six different topics: B-School Relevance, Teaching Relevance, Relevance to Practice, Curricula Relevance, B-School Evolution, and Influence, and Reputation. The longitudinal analysis identified four trends: Relevance to Practice, Social Relevance, Academic-Practitioner Divide, and Teaching Relevance. Through our bibliometric research, we contribute to the B-Schools research in two ways. It enabled the identification of works and themes that influenced reflections on B-Schools, as they influenced the ongoing research, and consequently, the research trends. Furthermore, the results serve as possible orientations for B-School managers.
\end{abstract}

\section{KEYWORDS}

Business Schools relevance, Bibliometrics, Business Schools Strategy

${ }^{1}$ Universidade Nove de Julho, São Paulo, SP, Brasil 


\section{INTRODUCTION}

Over the last few decades, there has been a proliferation of new courses at Business Schools (BS), especially the Master of Business Administration (MBA) (Collet \& Vives, 2013). Brazil has followed this trend, with a proliferation of MBA programs since the 1990s, with the belief among professionals and recruiters alike that an MBA is part of the criteria for professional success (Wood Jr. \& Cruz, 2014). BS are ranked in terms of legitimacy (Collet \& Vives, 2013) by their influence on students' choices (Sauder $\&$ Lancaster, 2006), employers' decisions, and their reputation for excellence (Dichev, 1999). The proliferation of BS and MBA programs is an important phenomenon, and a better understanding of the studies that have been conducted and the paths that research has followed is warranted.

There is growing awareness that the study of phenomena is important to the role and importance of research in order to provide an answer to everyday problems and enable learning in organizations (Doh, 2015). Phenomenon-based research focuses on understanding a phenomenon in the real world (Von Krogh et al., 2012). As mentioned above, understanding the phenomenon of BS, through their growth and influence on people and companies, is of great importance. Much has been written, but a brief search shows that no studies are available that have sought to understand the basis for this research and its intellectual evolution.

B-Schools have been severely criticized for a lack of relevance to practice and for not contributing effectively to students' careers (Pfeffer \& Fong, 2002). Further, concerns have been raised over curricula misalignment regarding, for example, soft skills (Navarro, 2008) and failure to prepare leaders and professional managers (Bennis \& O’Toole, 2005) properly. Despite the opportunity for management to take the lead in B-School research - "business schools are missing out because relatively few focus on work in this area" (Arbaugh, 2016, p. 238). Authors that discuss relevance also question the lack of theoretical support and empirical work regarding the critics and solutions (Augier \& March, 2011; Corley \& Gioia, 2011; Bartunek \& Rynes, 2014). Hence, further investigation is required to better understand (Gioia \& Corley, 2002) the management research that has been conducted and the paths that this research has followed.

To understand this phenomenon and its evolution, we conducted a bibliometric study of co-citation and bibliographic coupling. Bibliometric co-citation studies enable an analysis of references in articles in a given field to describe the content and evolution of research in that field. Coupling measures how frequently two documents in a sample share at least one common reference. This type of study delves the overlapping of bibliographies (Vogel, \& Güttel, 2013; Zupic \& Čater, 2015) and identifies the research trends in the field in question. The co-citation and bibliographic joint analysis were conducted up to 2015 , using the analysis of 76 articles and 38 references for the co-citation.

Our findings enable us to schematically show the influence of the intellectual basis of B-Schools' research and its influence on mainstream research. The relevance of B-Schools is still studied and discussed. The gap between theory and practice influences impacted the actual studies related with practice. The social relevance of B-Schools is reviewed in their evolution and influence. The social relevance is increased with the use experienced market professionals, but it did not reduce the concerns over the teaching at B-Schools and the studies on teaching techniques.

We present two main contributions to the B-Schools research. We identified the works and themes that influenced the ongoing research. We also identified the research trends of B-School research. Our work not only improves the understanding of and presents opportunities for future studies on B-Schools, but our findings offer some practical orientations for B-Schools managers. 


\section{RESEARCH METHOD AND TECHNIQUES}

17

\subsection{Data Collection Procedures}

The data were collected from the ISI Web of Science database. All business and management journals available were considered. The keyword business school* was used in the Topic field of the database to select the articles. The asterisk $\left({ }^{*}\right)$ was used so that any variation of the wording might be considered. The search outcome was examined to check if all articles in the sample were important to the analyses. The final sample considered the whole database search and contained 493 articles published in 19 journals (Table 1).

Table 1

Journals and number of articles selected

\begin{tabular}{|c|c|c|c|}
\hline Periódico & $\begin{array}{l}\text { Fator de Impacto } \\
\qquad 2017\end{array}$ & $\begin{array}{l}\text { Total de artigos } \\
\text { na amostra }\end{array}$ & $\%$ amostra \\
\hline Harvard Business Review & 4.374 & 178 & 36 \\
\hline Academy of Management Learning and Education & 2.866 & 146 & 29 \\
\hline British Journal of Management & 3.059 & 34 & 6 \\
\hline Organization Science & 3.027 & 24 & 4 \\
\hline Journal of Management Studies & 5.329 & 23 & 4 \\
\hline Academy of Management Journal & 6.700 & 14 & 2 \\
\hline Academy of Management Review & 8.855 & 14 & 2 \\
\hline California Management Review & 3.302 & 14 & 2 \\
\hline Organization & 2.701 & 13 & 2 \\
\hline Long Range Planning & 3.221 & 10 & 2 \\
\hline Administration Science Quarterly & 5.878 & 6 & 1 \\
\hline Journal of Management & 8.080 & 4 & 0 \\
\hline Academy of Management Annals & 9.281 & 3 & 0 \\
\hline Academy of Management Perspectives & 4.686 & 3 & 0 \\
\hline Asia Pacific Journal of Management & 2.474 & 2 & 0 \\
\hline Management Science & 3.544 & 2 & 0 \\
\hline Business Strategy and the Environment & 5.355 & 1 & 0 \\
\hline Management and Organizational Review & 1.462 & 1 & 0 \\
\hline \multirow[t]{2}{*}{ Strategic Management Journal } & 5.482 & 1 & 0 \\
\hline & & 493 & 100 \\
\hline
\end{tabular}

Source: Elaborated by the authors.

To reduce bias and ensure the validity and reliability of the selected studies, we set criteria for selecting the final sample (Vogel \& Güttel, 2013). The works had to have B-Schools as central theme. The authors read the title, the abstract, and the introduction of each document to validate the sample independently. Some documents were read in full to clarify occasional doubts. We obtained a Cohen-Kappa coefficient of .93 inter-reviewer agreement. 
Bibliometrics helps control biases brought by subjectivity which is usual in qualitative reviews performed without the help of empirical tools (Ramos-RodrigueZ \& Ruiz-Navarro, 2004). Moreover, through statistical analyses, large amounts of bibliographic data can be considered, bringing a broader scope than in purely qualitative reviews. (Vogel \& Güttel, 2013; Zupic \& Čater, 2015). Bibliometrics may be used as a prior step to guide the analysis during the systematic review. In this study, we used two bibliometric techniques - co-citation and bibliographic pairing.

The co-citation enables the measurement of the frequency in which a pair of articles is cited together (McCain, 1990). It is useful for detecting paradigmatic changes and schools of thought (Zupic \& Čater, 2015).

Bibliometric coupling is a measure of similarity based on the frequency that two documents of the sample share at least one common reference, i.e., the documents of a sample are grouped in accordance with the overlapping of its bibliographies (Vogel \& Güttel, 2013; Zupic \& Čater, 2015). The higher the number of shared references by two documents in the sample, the greater the similarity between them (Vogel \& Güttel, 2013).

Co-citation analysis was used first. With the aid of Bibexcel, a co-occurrence matrix (Bernard \& Ryan, 2010) of the references of each pair of articles in the sample was generated. The co-citation analysis was performed using the references of the sample of articles used for the bibliographic coupling. To run the bibliographic coupling, we reduced our sample and only articles with at least 6 couplings (ties $\geq 6$ ), with at least one document (node $\geq 1$ ) were preserved. The resulting reduced sample was composed of 76 articles.

This procedure enabled us to verify the intellectual structures that specifically influence the actual mainstream research agenda represented by these articles. For the bibliographic coupling analysis, using the same sample of 76 articles, an exploratory factor analysis, aiming to group the articles by their similarity, was performed. We performed a citation analysis of the references used in the sample (File link: https://drive.google.com/file/d/16-KfNKpXdbhhTxRHdrV2pvBRjoSY4x0s/ view? usp=sharing).

For the bibliographic coupling analysis, the co-occurrence matrix generated was used and it was complemented by factor analysis and the network diagram. The former employed Varimax rotation (Lin \& Cheng, 2010). Factor loads of approximately 0.4 or higher were considered (Guerrazzi et al. 2015).

All the articles that compose each factor, for both bibliographic coupling and co-citation analyses, were read to enable the understanding of their content. We used two clustering methods to increase robustness (Zupic \& Čater, 2015). Network analysis allows the visualization of the intellectual structure of a field through a network diagram, with nodes representing publications and loops representing their sharing relationship. Therefore, the factors were used and overlapped in the network diagram provided by Ucinet software (Lin \& Cheng, 2010). The network shows the proximity between articles and their connections, representing the relationship and dimension of the number of articles all together.

We also reported density, cohesion, and centrality, which are usual metrics for network analysis (Vogel \& Güttel, 2013). Density represents the extent to which a factor has common conceptual bases, and its maximum value is obtained when all possible links between references of the same factor are exhausted (Vogel \& Güttel, 2013). It is an internal indicator of the factor. In co-citation, the maximum density indicates that references grouped in the same factor have independence in the expression of an approach, as they are referenced together. In pairing, it indicates that items of a factor, having their focus defined by grouping, employ common references. 
BBR

17

462

Cohesion equals the density of a factor in its interconnection with other groups, indicating the degree of independence that the factor represents (Wasserman \& Faust, 1994). It is an inter-factor indicator. For both citation and bibliographic matching, cohesion complements the explanation of density with respect to the power of convergence between items of the same factor. Network centrality means groupings formed around the most cited articles. It is measured by the number of links each item establishes on the network - the more links the more central the item., covering the whole network. The centrality highlights the relevance of this work throughout the network as it is more often cited in conjunction with another (co-citing) or shares references in large numbers with other articles (pairing).

Focusing on an investigation of the influence of the literature structure on the ongoing works about B-schools, we conducted a jointly analysis with co-citation and coupling results. To achieve this aim, a co-occurrence matrix was created for the references that constitute the co-citation factors and for the articles from the coupled analysis. In this matrix, co-citation references were the lines and the bibliographic coupling articles were the columns, both grouped into the previously obtained factors. The crossing between lines and columns was binarized, and we filled it with " 1 " if such a reference was used in any of the articles and " 0 " if not. This matrix made it possible to gauge the influences of the intellectual roots (co-citation) in current research (bibliographic coupling) and present the values and relationships graphically (Figure 1).

Figure 1. Intellectual structure and mainstream research on B-Schools.

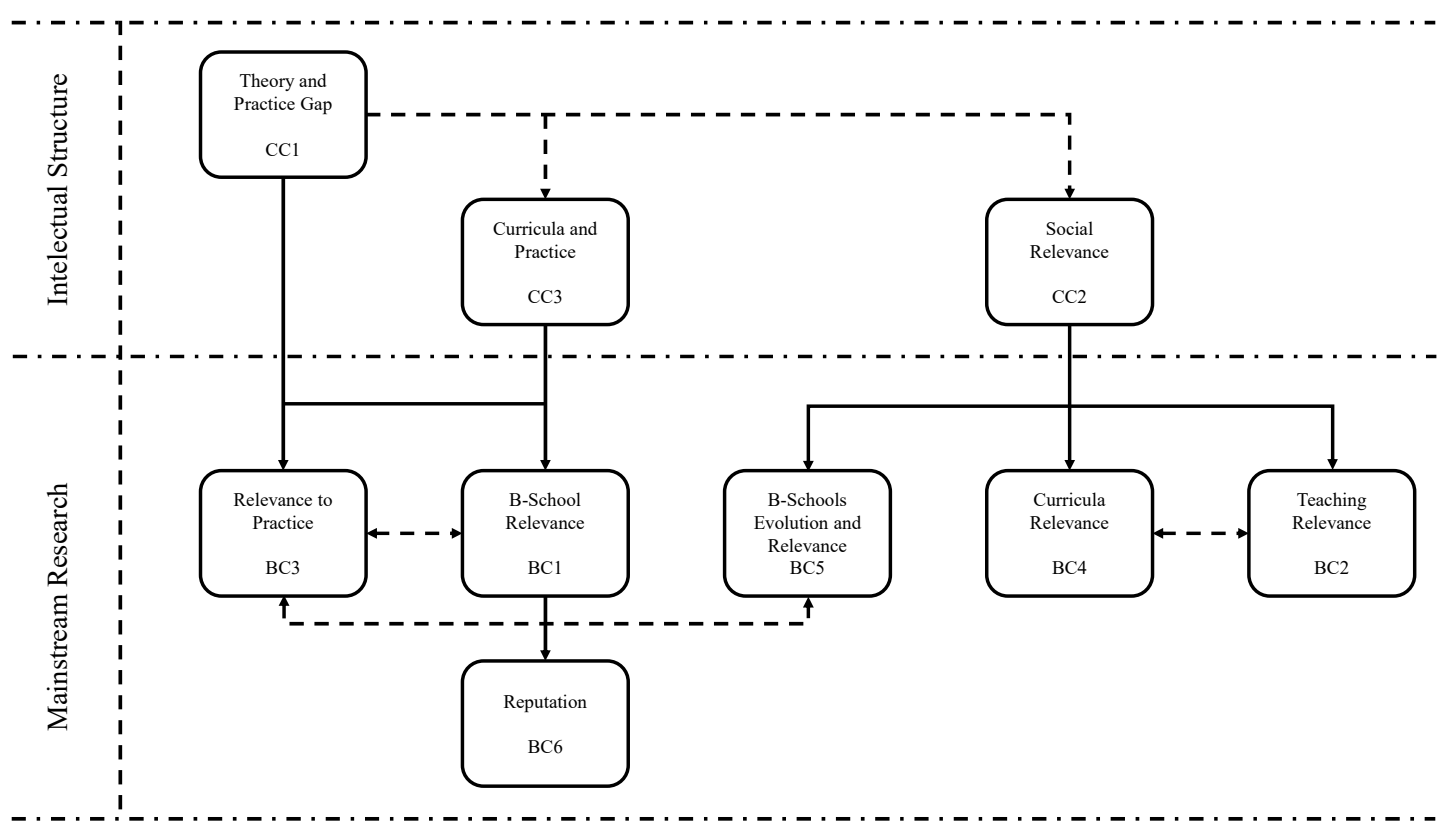

Source: Elaborated by the authors.

To verify the influences of the references (co-citation) in the articles (bibliographic coupling) we made a cross-analyses of references in the articles. Since they constitute articles and references, and these structure the approach of an article, this analysis makes it possible to gauge the direct influence between the basic approaches with the streams of research used to investigate our theme. 


\section{INTELECTUAL STRUCTURE AND ONGOING STUDIES IN B-SCHOOLS}

The influence of the intellectual structure on the mainstream research on B-Schools is depicted in Figure 1. This figure, that is orienting our review, was created through the results of the bibliometric analysis available in the Appendix 1. We preserve the identification of the factors of the results, where $\mathrm{CC}$ are factors from the co-citation, and $\mathrm{BC}$ from the bibliographic coupling.

Figure 1 schematically presents the main influence among the factors that serve as an intellectual basis, and that initiated studies on B-Schools, along with more recent research (ongoing discussions). The articles that constitute the intellectual base from the 1980s to the mid-2000s are mostly conceptual articles, although some are qualitative, with criticisms of B-Schools. There is one predominant criticism of B-Schools, which is the theory and practice gap (Factor CC1), with scholars questioning the relevance of research and either consulting practices for practitioners. This factor has a secondary impact on the others in the intellectual structure base. In a way, it poses a challenge to rethink the relevance of the services provided by business schools and their relevance to society (Factor CC2), and through curricula and its applicability in practice (Factor CC3). To a certain extent, the factors question managers that are being trained in B-Schools, the relevance of their role, and the importance of what they teach. Nevertheless, concern over how to teach is not emphasized. It should be pointed out that, during this time, most articles focused on B-Schools in North America and UK.

The relevance of B-Schools for the market (CC3) continues to be studied and discussed (Factor $\mathrm{BC} 1$ ) and related with their search for legitimacy and reputation. As the theory and practice gap (CC1) considering its relationship with practice (Factor BC3). The social relevance of B-Schools is reviewed in their evolution and influence (BC5). Despite the use experienced professionals from the market (Factor BC4), concerns have also been raised over the teaching at B-Schools and how teaching techniques are used in this respect (Factor BC2), to be socially relevant (Factor CC2). Each of the factors will be further explored.

\subsection{InTELLECTUAL STRUCTURE IN B-SChOOLS}

Factor CC1 was labeled “Theory and Practice Gap”. The central works of the network are present in this factor: Starkey \& Madan (2001); Van de Ven \& Johnson (2006); Van de Ven (2007). These articles present arguments regarding the lack of relevance of B-School research to practice.

The authors in this factor argue that knowledge is increasingly produced and distributed socially (Gibbons et al., 1994) and hence, by its nature, management research should be applied (Tranfield \& Starkey1998). The main focus is on the need to rethink the science (Nowotny et al., 2001) and develop the link between theory and practice (Hambrick, 1994). This creates a discussion regarding the Kuhnian model of normal science (Kuhn, 1962) and problem-solution research, which is more socially distributed (Gibbons et al., 1994; Tranfield \& Starkey, 1998; Anderson, Herriot \& Hodgkinson, 2001). Shapiro, Kirkman and Courtney (2007) add that the gap should be interpreted as the result of two distinct translation problems: "lost before translation", where the knowledge produced does not have any chance to make an impact on practice and, a "lost in translation" problem - where knowledge production is not adequately translated into practice. 
BBR

17

464

Nevertheless, the creation of knowledge is a complex process (Grey, 2001), and has to be considered in different paradigms (Pfeffer, 1993), with a thought for scientific rigor in the link between theory and practice (Van de Ven, 2007). However, the weak union of theory and practice is brought into question, with several studies deemed as being of little relevance to managers (Van de Ven \& Johnson, 2006). The principles from research evidence should be translated into practice to solve organizational problems (Rousseau, 2006), and to help train managers to deal with real challenges throughout their careers (Leavitt, 1989). In B-Schools, managers should collaborate with their knowledge (Starkey \& Madan, 2001).

Factor CC2, is named "Social Relevance". The articles reinforce the relevance and social role of B-Schools, and the criticisms of the impact of rankings and accreditations on them (Navarro2008; Gioia and Corley2002; Adler \& Harzing, 2009). Concerns over B-Schools' relevance and social role are not new (Cheit, 1985; Gordon \& Howell, 1958), and the need for change is emphasized by the authors in this factor who argue for trends to be considered in relation to both supply and demand in the education of managers (Friga, Bettis \& Sullivan, 2003). There is a call for B-Schools to consider a global perspective to have social relevance, as well as thethe development of leadership and soft skills, and greater integration of disciplines to improve decision-making skills (Datar et al., 2010; Bennis \& O’Toole, 2005). It is claimed that B-Schools should be more relevant to practitioners (Porter \& McKibbin, 1988).

The fact that certain theories are treated as actual practices, irrespective of their social impact, has been questioned (Ferraro, Pfeffer \& Sutton, 2005; Ghoshal, 2005). The ethical scandals provoked by managers of organizations show that B-Schools need to start considering ethical aspects and go beyond focusing on financial results (Ghoshal, 2005; Bennis \& O’Toole, 2005). Changing the curriculum at B-Schools should mean multidisciplinary integration (Navarro, 2008; Bennis \& O’Toole, 2005; Porter \& McKibbin, 1988) and the development of B-Schools as forums for citizens and places for social networking (Starkey $\&$ Tiratsoo, 2007).

We labeled Factor CC3 as "Curricula and Practice". B-Schools are criticized because of the pressure to achieve financial results (Khurana, 2007), which is fostered by the student's belief that what is taught at B-Schools will aid an individual's personal and professional growth (Pfeffer \& Fong, 2004). The relationship with practice is necessary (Mintzberg \& Gosling, 2002; Rynes, Bartunek \& Daft, 2001). They advocate the need to create knowledge for management (Starkey, Hatchuel \& Tempest, 2004). Curricula should address real problems (Pfeffer \& Fong, 2002; Starkey \& Tempest, 2009), and focus on managers' competence development (Rubin \& Dierdorff, 2009). B-Schools should consider experience and meaning in the learning process, which transcends the classroom (Mintzberg \& Gosling, 2002), and implies changes for how managers are taught (Mintzberg, 2004) e.g., through evidence-based teaching (Pfeffer \& Sutton, 2007) that enables "managerial decisions and organizational practices informed by the best available scientific evidence” (Rousseau \& McCarthy, 2007, p. 84). B-Schools should consider the balance between acquiring knowledge through research and exploiting knowledge through instruction (Trieschmann et al., 2000).

\subsection{Ongoing STUdies In B-Schools}

Factor BC1 is labeled as "B-School Relevance". The challenge posed by the authors in this factor is to prepare people with the necessary competences for the market and society (Walsh, 2011). B-Schools emphasize theory at the expense of relevance to practice (McGrath, 2007). Some 
criticisms argue that B-Schools cannot fulfil this important role to prepare leaders (Benjamin \& O'Reilly, 2011), and so make no difference to their careers (Pfeffer \& Fong, 2004). Others stress that the leadership developed in B-Schools reflects negative values and actions without concern for society, and that there is a need for gender diversity for more humanized executives (McTiernan \& Flynn, 2011). Business schools are the potential workspaces, not only to improve knowledge, but also to influence managers' identity for such humanized leadership (Petriglieri \& Petriglieri, 2010; Petriglieri, Wood, \& Petriglieri, 2011).

To overcome these criticisms, several models were proposed (Ferlie, McGivern, \& Moraes, 2010; Thomas \& Wilson, 2010): the "Agora" as an open platform for discussion and development (see Starkey \& Tiratsoo, 2007); the schools in the professional model (see Bennis \& O’Toole, 2005); and the business school public interest model, which operates to the interest of society (Ferlie, McGivern \& De Moraes, 2010).

Some authors have suggested that B-Schools need to revise their purposes, curricula, and pedagogy, despite the institutionalized organizational form and search for legitimacy that inhibit change (see Wilson \& McKiernan, 2011). The challenge of relevance is a question of behavioral competencies (Rubin \& Dierdorff, 2011), which are valued by organizations (Safon, 2007). This means that the nature of knowledge produced and taught in B-Schools should be reviewed (Chia \& Holt, 2008), and scholarly impact should be evaluated not only through academic publications, but also through its impact on students (Morgerson \& Nahrgang, 2008).

The authors make several suggestions, such as the inclusion of disciplines like humanities (Bennis \& O’Toole, 2005; Schoemaker, 2008), requiring a distinct teaching curriculum and pedagogical approach (Harrison, Leitch, \& Chia, 2007). Vaara and Fay $(2011 ; 2012)$, for example, presented a Bourdieusian perspective for management education. The development of leadership skills (Kork, 2011) should include business ethics (Rutherford et al., 2012), decision-making (Henisz, 2011), and sustainability (Slater, Dixon \& Fowler, 2010), as well as how to perform in emerging markets (Dhanaraj \& Khanna, 2011), supported by Evidence-based Management (Charlier, Brown, \& Rynes, 2011) in a B-School's curriculum.

However, some authors counter the criticisms of B-Schools' relevance, for example, as posed by Pfeffer \& Fong (2004). O’Brien et al. argue that the: “research conducted at business schools is relevant and valuable to practitioners as evidenced by the considerable long-term economic value added to MBA student salaries." (O’Brien et al. 2010, p.648)

Further, Slater, Dixon \& Fowler (2010) argue that executives who graduated from B-Schools present positive results in regards to sustainability. Arbaugh (2010) advocates that the article of Peng and Dess (2010) "not only challenges the notion that management scholarship is deficient but argues that in fact the systems and assessment mechanisms presently in place to evaluate the worth of our publications serve a positive role in motivating us to produce better work than what we might have otherwise." (Arbaugh, 2010, p. 280).

Factor BC3 was named "Relevance to practice". The discussion of relevance is important in the US and UK (Butler, Delaney, \& Spoelstra, 2015), but in Factor 3, there is a different focus from Factor BC1. It seems to be a UK research focus that discusses the academy-practitioner divide and evaluates possible remedies. Some authors claim that research is not relevant to practice (McKelvey, 2006). Bell, den Ouden and Ziggers argued that "it is neither built upon a minimal consensus of paradigmatic beliefs, resulting in [...] an academic gap, nor capable of providing practitioners with adequate answers, what we call a managerial relevance gap." (Bell et al. 2006, p. 1615) 
BBR

17

466

Other authors defend research and believe it can be relevant in practice (Sandberg \& Tsoukas, 2011). A central idea is to achieve engagement and collaboration between academics and practitioners (Hughes et al. 2011; - see co-citation Factor CC1 for Van de Ven, 2007, Van de Ven \& Johnson, 2006; Starkey \& Madan, 2010). The collaboration between academics and practitioners would be a possibility for co-creation of relevant knowledge (Antonacopoulou, 2010). This relationship, despite other tensions, should consider the need for impartial research against short-term results demanded by practitioners (Tushman et al. 2007). Therefore, some authors advocate that the academy-practitioner divide will remain unsolved, as science and practice have different meanings for researchers and practitioners (Kieser \& Leiner, 2009, 2011; Nicolai \& Seidl, 2010). Kieser and Leiner (2009) argue that the relationship between academics and practitioners would not be adequate for research but would be feasible to solve practical problems. Academics may orient towards practitioners "in ways that contravene their academic identity and research ethos" (Butler, Delaney, \& Spoelstra, 2015, p. 732).

In general, the authors agree with the research relevance gap and the need to better understand relevance (Priem \& Rosenstein, 2000; Learmonth, Lockett \& Dowd, 2012; Parnell et al. 2012). This led authors to discuss the suggestion of possible remedies and their effectiveness. This is highlighted in the UK discussion of methodological alternatives to Mode 1 knowledge (Knights, 2008) like Mode 2 (Stiles, 2004; Knights, 2008) and other possibilities like Mode 3 research, engaged scholarship, pragmatic science, and evidence-based management (Romme et al. 2015).

Factor BC4 was labelled "Curricula Relevance". The factor has a low explained variance with $5.17 \%$. Here, B-Schools are questioned about their lack of relevance to business practice and the authors defend models that bring practice to the student, as in medical schools (Pfeffer $\&$ Fong, 2002). Pfeffer and Fong remarked that this: "entails focusing research on phenomena and problems of enduring importance, and building curricula that are evaluated, in part, by how well they actually prepare students to be effective in practicing the profession." (Pfeffer $\&$ Fong, 2002, p. 93)

This implies a curricular program closer to the real-life challenges facing professionals and the development of competences for their professional activities (Navarro, 2006; 2008). Clinebell and Clinebell (2008) argue that there are two challenges facing B-Schools here: the shortage of faculty members with doctoral degrees and the lack of relevance. One of the remedies for resolving this would be to solve the tensions concerning the integration and use of executive professors or professional qualified faculty members.

Factor BC5 was identified as "B-School evolution and influence". Here, recognition of the evolution of B-Schools appears in discussions between the authors (Augier \& March, 2005; 2007; Augier \& Teece, 2005; Khurana \& Spender, 2012), as well as the discussion of fashionable theories (Abrahamson, 1996; Bort \& Kieser, 2011). The evolution of B-Schools showed a transition from conducting research driven by the real world to theory driven research almost detached from its problems and contexts (Augier \& March, 2005; 2007; Augier \& Teece, 2005; Khurana \& Spender, 2012). The evolution reflects the ideal of Simon, where "knowledge from practice" and "knowledge from the disciplines" are integrated (Khurana \& Spender, 2012). B-Schools are where researchers are, and researchers create fashion (Bort \& Kieser, 2011). B-Schools should be the primarily fashion theory setters. Scholars should research and learn how to settle fashionable theories (Abrahamson, 1996).

Factor BC6 is named "Reputation". This factor includes studies that directly (Baden-Fuller, Ravazzolo, \& Schweizer, 2000) or indirectly consider the influence of rankings on B-Schools (Rindova, et al. 2005; Macdonald \& Kam, 2007; Rindova, Williamson, \& Petkova, 2010). The 
media rankings, which include the MBAs of B-Schools, have a strong influence on reputation and consequently, the possibility of charging premium fees (Rindova et al. 2005). The indirect effect of the rankings of periodicals on publications (Rindova, et al. 2005; Macdonald \& Kam, 2007) and works of research is also recognized (Ofori-Dankwa \& Julian, 2005). B-Schools, as part of a HEI, would also suffer the effect of this relationship (Rindova et al. 2005). The research

of Rindova et al. (2005) provided empirical support for the positive effect of academic research on B-Schools' reputation.

Factor BC2 was named "Teaching Relevance" with an aim to make a difference to society (Tsui, 2013; Walsh, 2012). Most of the articles focus on the teaching of management; testing tools (Wright, Paroutis, \& Blettner, 2013); studying evidence-based management (Trank, 2014; Gamble \& Jelley, 2014; Klimoski \& Amos, 2012); design thinking (Glen, Suciu, \& Baughn, 2014); or, combining design science with critical realism (Willmott, 2012). Other articles focus on management and sustainability (Shrivastava, Ivanaj, \& Persson, 2013; Aguinis et al., 2014; Akrivou \& Bradbury-Huang, 2015); addressing concerns over how B-Schools are teaching management (Knights \& Clarke, 2014; Costigan \& Brink, 2015); and, making suggestions to improve teaching (Waddock \& Lozano, 2013).

Other authors question the metrics used to evaluate scholarly performance and the legitimacy paradox that B-Schools face (Alajoutsijarvi, Juusola, \& Siltaoja, 2015). As mentioned by Aguinis et al. (2014), the "majority of inquiry on scholarly impact has focused almost exclusively on one particular stakeholder and one type of measure: academics and citations." (Aguinis et al., 2014, p. 624).

\section{DISCUSSION AND FINAL REMARKS}

Through our bibliometric research, we contribute to B-School research in two ways. First, we enabled the identification of works and themes that influenced reflections on B-Schools, and, second, how they influenced the ongoing research, and consequently, the research trends (Figure 1). Furthermore, the results serve as practical orientations for B-School managers.

The network and factor analyses enabled us to detect the topics that are preferentially studied and their relationship with the studies that serve as a basis for current mainstream research. Through the intellectual structure, we could say that the entire field is responding to the call for works from Gioia and Corley (2002) and Pfeffer and Fong (2004), questioning B-Schools' relevance to practice. The relevance of B-Schools is questioned regarding the theory and practice gap, social relevance, and the adequacy of the curricula to practice. These themes impacted current research on B-Schools.

The study of B-Schools was motivated by the theory-practice gap - a question of relevance. The relevance gap may be divided into two fronts: the questioning of the relevance of research to practice, and the questioning of the possibility of delivering the knowledge produced to managers. It raises the question of the need for rigor and relevance in co-creating knowledge with practitioners. The questioning of the role and relevance of B-Schools may be divided into two influencing topics. One is questioning the social role of B-Schools requesting to consider their primary mission, to prepare managers in a way that would have a positive impact on their careers and a positive effect on society. Another, and also a related topic, is the relevance of the teaching at B-Schools - teaching for personal growth and its relationship to practice. There is a need to focus not only on new contents but also to develop personal competencies. To do that, new forms of pedagogy are necessary and will need to filter up to the classroom. The challenge is not only acquiring knowledge from research but exploiting it through practice. 
B-School relevance continues to be questioned. The authors continue to question why B-Schools failed to form leaders and to make a difference in managers' careers. They claim that in order for B-Schools to be relevant to society, they should be a place to influence managers and to develop more humanized leadership. The main difference from the intellectual structure is that, even in conceptual articles and some case studies, authors on this topic offer suggestions to circumvent criticism. They reinforce the need to review the contents and focus on managers' competence development. It is related to the influence of positive or negative media rankings that drives B-Schools to gain legitimacy and improve their reputation.

Despite the pertinence of the criticisms, these works were predominantly essays, that influence the mainstream works on B-Schools. We would expect to find articles discussing B-Schools' management and the institutional factors in the mainstream. We are not saying that these studies do not exist, but they did not appear predominant in our selection. Management would influence B-School choices and the use of their resources and choice of course of action.

Considering the claim of Gioia and Corley (2002), external forces will influence management decisions, and in our view, influence all the topics that we presented in this work. Although many other research fronts may emerge in the agenda proposed from the results of this study, we think that the suggested research topics and revision of the influence of rankings and scholar evaluation would help B-Schools gain more relevance and increase their importance to students and society.

We argue that B-Schools need to become relevant to the market and to society. They should produce relevant research results and be concerned with preparing students for the market, using adequate professors, and teaching techniques. However, in their drive for legitimacy, B-Schools tend to become homogeneous concerning the content of their teaching, focusing on managerial fads due to isomorphic pressures (coercive, mimetic, and normative) that stem from the accreditations and rankings that they are anxious to achieve. Works like Wilson and McKiernan (2011) allow us to suggest that future studies should evaluate the influence of isomorphic pressures on the strategic choice of managers of BS and the adaptation of resources. It would be interesting to understand the hierarchy of isomorphic pressures on B-Schools in the process of seeking legitimacy and earning a reputation.

The world proliferation of MBA programs since the 1990s (Collet \& Vives, 2013) suggest the need, not only to include an international perspective in MBA programs (Dhanaraj \& Khanna, 2011), but also to understand the international competition for students, international collaboration and B-Schools from emerging countries.

B-Schools need to align their curricula considering changes in society, and students' needs. B-Schools should be the locus for nurturing positive values and preparing leaders. It poses a challenge, not only in terms of content but also in professional professors and pedagogical challenges.

The call for curriculum alignment with the reality and challenges of society should be investigated, eventually considering the need to develop leaders and managers for a new and future reality, not considering disciplines, but instead developing critical reflection and competences (Benjamin \& O’Reilly, 2011). It demands new pedagogical forms of teaching that are being developed and used in undergraduate courses for executive education (Scafuto et al. 2017), as well as other calls (Charlier, Brown, \& Rynes, 2011).

A second significant stream in B-School research is Relevance to Practice, which is directly related to the discussion of knowledge diffusion or transfer, and the academic-practitioner divide. UK scholars appear to be more dedicated to this discussion. We belive that the academicpractitioner engagement is a promising area for further research (Van de Ven \& Johnson, 2006). 
Future studies should continue to investigate the possibilities of research modes of knowledge development (Stiles, 2004; Knights, 2008; Romme et al., 2015), even with the possible tensions between the practitioners and scholars' system of thinking (Kieser \& Leiner, 2011; Nicolai \& Seidl, 2010). Another possible investigation is considering scholars' engagement in executive arenas like business consulting (Butler, Delaney, \& Spoelstra, 2015). It is important for business schools to return to being the management fashion setter (Abrahamson, 1996), responding to Hambrick's (1994) call for increased self-promotion by academics.

A consequent emerging and independent topic is Teaching Relevance, which appears to be predominant and of interest among American scholars. These articles focus on discussing fees and teaching methods, with an important discussion of evidence-based management. Our perception, however, is that this research, which ought to focus on empirical applications, appears to remain casuistic and conceptual. Our observations led us to agree that B-School research needs to become a structured field of study. However, in its current state, it seems to lack empirical and theoretical support (Augier \& March, 2011; Corley \& Gioia, 2011; Bartunek \& Rynes, 2014).

The studies recommend further research to gain a better understanding of the phenomenon. Generally, the phenomenon appears to require more empirical studies in distinct context settings, including outside the USA and Europe, in emerging economies (Dhanaraj \& Khanna, 2011). Relevance to practice seems to test the proposals from the predominant essays and conceptual works.

Another contribution is the unique method used in this article, especially joining co-citation and bibliographic coupling analysis, which seems to provide a possibility for future bibliometric studies, enabling a better understanding of fields and phenomena.

This study has limitations regarding its method, as it is a bibliometric study. Future studies could include the Scopus database. This base contains several journals on higher education that are not included in the base used for the present study. However, most of the journals mentioned are not directly related to management, which was our focus, but mainly with the sociology of education. Another limitation was the use of the chosen keyword for research. The verification of complementary keywords attenuated this limitation in the selected articles that did not result in a significant change in the sample. Other possible limitations were mitigated by the use of two complementary methods of analysis (factor and network), and conducting a joint study of co-citation and coupling.

The study of B-Schools, despite its growth, can still be considered recent if we consider that most of the articles were published less than 30 years ago. It could be said that, due to the existence of many fields related to criticisms, understanding the strategic behavior of B-Schools through their importance to, and influence on, executives will require a great deal of further study. As predicted by Gioia and Corley (2002), in the first issue of AMLE, "the Circe-like transformation of business schools from substance to image, [is] a phenomenon that deserves our understanding and proactive engagement." Considering the importance of the topic, and the authors that emerge from our study, we have to enhance the question raised by the late Prof. Arbaugh, "Where are the dedicated scholars of management learning and education?" (Arbaugh, 2016, p. 230), in this case, B-Schools. The importance, and foremost, the potential benefit of having relevant B-Schools, considering research and teaching, to prepare and have a positive influence on future leaders is paramount to having engaged and dedicated researchers. 


\section{REFERENCES}

17

470
Abrahamson, E. (1996). Management Fashion. Academy of Management Review, 21(1), 254-285.

Adler, N. \& Harzing, A., (2009). When Knowledge Wins: Transcending the sense and nonsense of academic rankings. Academy of Management Learning and Education, 8(1), 72-95.

Aguinis, H., Bradley, K. J., \& Brodersen, A. (2014). Industrial-organizational psychologists in business schools: Brain drain or eye opener? Industrial and Organizational Psychology: Perspectives on Science and Practice, 7(3), 284-303.

Akrivou, K., \& Bradbury-Huang, H. (2015). Educating integrated catalysts: Transforming business schools Toward ethics and sustainability. Academy of Management Learning and Education, 14(2), 222-240.

Alajoutsijärvi, K., Juusola, K. \& Siltaoja, M. (2015). The Legitimacy paradox of Business Schools: Losing by gaining? Academy of Management Learning and Education, 14(2), 277-291.

Alferoff, C. \& Knights, D. (2009). Making and Mending your Nets: Managing Relevance, Participation and Uncertainty in Academic-Practitioner Knowledge Networks. British Journal of Management, 20(1), $125-142$.

Anderson, N., Herriot, P. \& Hodgkinson, G. P. (2001). The practitioner-researcher divides in industrial, work and organizational psychology. Journal of Occupational and Organizational Psychology, 74(4), 391-411.

Antonacopoulou, E.P. (2010), Making the Business School More 'Critical': Reflexive Critique Based on Phronesis as a Foundation for Impact. British Journal of Management, 21(Special Issue), s6-s25.

Arbaugh, J. (2010). Do undergraduates and MBAs differ online? Initial conclusions from the literature. Journal of Leadership and Organizational Studies, 17(2), 129-142.

Arbaugh, J. (2016.) Where are the dedicated scholars of management learning and education? Management Learning, 47, 230-240.

Augier, M. \& March, J. (2007). The Pursuit of relevance in management education. California Management Review, 49(3), 129-146.

Augier, M. \& March, J. (2011). The roots, rituals, and rhetorics of change: North American business schools after the Second World War. Stanford, CA: Stanford Business Books.

Augier, M. \& Teece, D. J. (2005). Na economics perspective on intellectual capital. In B Marr (Ed) Perspectives on Intellectual Capital, Oxford: Elsevier.

Augier, M., March, J. \& Sullivan, B. N. (2005). Notes on the evolution of a research community: Organization Studies in Anglophone North America, 1945-2000. Organization Science, 16 (1), 85-95.

Baden-Fuller, C., Ravazzolo, F. \& Schweizer, T. (2000). Making and measuring reputations: the research ranking of European business schools. Long Range Planning, 33(5), 621-650.

Bartunek, J. \& Rynes, S. (2014). Academics and practitioners are alike and unlike: The paradoxes of academic-practitioner relationships. Journal of Management, 40, 1181-1201.

Bell, J. Den Ouden, B., \& Ziggers, G. (2006). Dynamics of cooperation: At the brink of irrelevance. Journal of Management, 43(7), 1607-1619.

Benjamin, B. \& O’Reilly, C. (2011). Becoming a leader: Early career challenges faced by MBA Graduates. Academy of Management Learning and Education, 10(3), 452-472. 
Bennis, W. \& O’Toole, J. (2005). How business schools lost their way. Harvard Business Review, 83, 96-104.

Bernard, H. \& Ryan, G. (2010). Analyzing qualitative data: Systematic approaches. Thousand Oaks: Sage Publications, Inc.

Bort, S. \& Kieser, A. (2011). Fashion in organization theory: An empirical analysis of the diffusion of theoretical concepts. Organization Studies, 32(5), 655-681.

Butler, N., Delaney, H. \& Spoelstra, S. (2015). Problematizing "Relevance" in the Business School: The Case of Leadership Studies. British Journal of Management, 26, 731-744.

Charlier, S., Brown, K. \& Rynes, S. (2011). Teaching evidence-based management in MBA programs: What evidence is there? Academy of Management Learning and Education, 10(2), 222-236.

Cheit, E. (1985). Business Schools and Their Critics. California Management Review. 27(3), 43-62.

Chia, R. \& Holt, R. (2008). The nature of knowledge in business schools. Academy of Management Learning and Education, 7(4), 471-486.

Clinebell, S. \& Clinebell, J.M. (2008). The tension in business education between academic rigor and real-world relevance: The role of executive professors. Academy of Management Learning and Education, 7(1), 99-107.

Collet, F. \& Vives, L. (2013). From preeminence to prominence: The fall of U.S. Business Schools and the rise of European and Asian Business Schools in the Financial Times Global MBA Rankings. Academy of Management Learning and Education, 12(4), 540-563.

Corley, K. \& Gioia, D. (2011). Building theory about theory building: What constitutes a theoretical contribution? Academy of Management Review, 36, 12-32.

Costigan, R. \& Brink, K. (2015). On the prevalence of linear versus nonlinear thinking in undergraduate business education: A lot of rhetoric, not enough evidence. Journal of Management and Organization, 21(4), 535-547.

Datar, S., Garvin, D. \& Cullen, P., (2010). Rethinking the MBA: Business Education at a Crossroads. Boston, MA: Harvard Business Press.

Dhanaraj, C. \& Khanna, T. (2011). Transforming mental models on emerging markets. Academy of Management Learning and Education, 10(4), 684-701.

Dichev, I. (1999). How good are business school rankings? Journal of Business, 72(2), 201-213.

Doh, J. (2015). Why we need phenomenon-based research in international business. Journal of World Business, 50(4), 609-611.

Ferlie, E., McGivern, G., \& De Moraes, A. (2010). Developing a Public Interest School of Management. British Journal of Management, 21(S1), 60-70.

Ferraro, F., Pfeffer, J. \& Sutton, R. (2005). Economics language and assumptions: How theories can become selffulfilling. Academy of Management Review, 30(1), 8-24.

Friga, P., Bettis, R. \& Sullivan, R., (2003). Changes in graduate management education and new business school strategies for the 21st century. Academy of Management Learning and Education, 2(3), 233-249.

Gamble, E. \& Jelley, R. (2014). The case for competition: Learning about evidence-based management through case competition. Academy of Management Learning Education, 13(3), 433-445. 
BBR

17

472

Ghoshal, S. (2005). Bad management theories are destroying good management practices. Academy of Learning Education, 4(1), 75-91.

Gibbons, M., Limoges, C., Nowotny, H., Schwartzman, S., Seot, P. and Trow, M., (1994). The new production of knowledge: The dynamics of science and research in contemporary societies. SAGE, London.

Gioia, D. \& Corley, K. (2002). Being Good Versus Looking Good: Business School Rankings and the Circean transformation from substance to image. Academy of Management Learning and Education, 1 , 107-120.

Glen, R., Suciu, C. \& Baughn, C. (2014). The Need for Design Thinking in Business School. Academy of Management Learning and Education, 13(4), 653-667.

Gordon, R. \& Howell, J. (1958). Higher Education for Business. Columbia University Press.

Grey, C. (2001). Re-imagining Relevance: A Response to Starkey and Madan. British Journal of Management, 12(SI), 527-S32.

Grey, C. (2004). Reinventing Business Schools: The Contribution of Critical Management Education. Academy of Management Learning and Education, 3(2), 178-186.

Guerrazzi, L., Brandão, M., Campos Junior, H. \& Lourenço, C. (2015). Pesquisa em marketing e estratégia nos principais periódicos internacionais: um estudo bibliométrico sobre publicações no século XXI. Revista Ibero-Americana de Estratégia, 14(1), 7-27.

Hambrick, D. (1994). What if the Academy actually mattered? Academy of Management Review, 19(1), $11-16$.

Harrison, R., Leitch, C. \& Chia, R. (2007). Developing paradigmatic awareness in university Business Schools: The challenge for executive education. Academy of Management Learning and Education, 6(3), 332-343.

Henisz, W. (2011). Leveraging the Financial Crisis to Fulfill the Promise of Progressive Management. Academy of Management Learning and Education, 10(2), 298-321.

Hodgkinson, G. \& Starkey, K. (2011). Not Simply Returning to the Same Answer Over and Over Again: Reframing Relevance. British Journal of Management, 22(3), 355-369.

Hughes, T., D. Bence, L. Grisoni, N. O’Regan \& D. Wornham (2011). Scholarship that matters: academic-practitioner engagement in business and management. Academy of Management Learning and Education, 10(1), 40-57.

Kark, R. (2011). Games managers play: Play as a form of leadership development. Academy of Management Learning and Education, 10(3), 507-527.

Khurana, R. \& Spender, J. C. (2012). Herbert A. Simon on what ails business schools: more than a problem in organizational design. Journal of Management Studies, 49(3), 619-639.

Khurana, R. (2007). From higher aims to hired hands: the social transformation of American business schools and the unfulfilled promise of management as profession. Princeton: Princeton University Press.

Kieser, A. \& Leiner, L. (2009) Why the rigour-relevance gap in management research is unbridgeable. Journal of Management Studies, 46(3), 516-533.

Kieser, A. \& Leiner, L. (2011). On the Social Construction of Relevance: A Rejoinder. Journal of Management Studies, 48(4), 891-898.

Kieser, A. \& Leiner, L. (2011). On the social construction of relevance: A rejoinder. Journal of Management Studies, 48, 891-898. 
Klimoski, R. \& Amos, B. (2012). Practicing. Evidence-Based Education in Leadership Development. Academy of Management Learning and Education, 11(4), 685-702.

Knights, D. \& Clarke, C. (2014). It's a bittersweet symphony, this life: Fragile academic selves and insecure identities at work. Organization Studies, 35(3), 335-357.

Knights, D. (2008). Myopic Rhetorics: Reflecting Epistemologically and Ethically on The Demand for Relevance in Organizational and Management Research. Academy of Management Learning and Education, 7(4), 537-552.

Knights, D. (2008). Myopic rhetorics: Reflecting epistemologically and ethically on the demand for relevance in organizational and management research. Academy of Management Learning and Education, 7, 537-552.

Kolb, D., (1984). Experiential learning: Experience as the source of learning anddevelopment. New Jersey: Prentice-Hall.

Kuhn, T., (1962). The Structure of Scientific Revolutions. Chicago: The University of Chicago Press.

Learmonth, M., Lockett, A. \& K. Dowd (2012). Towards scholarship that matters: the usefulness of useless research and the uselessness of useful research. British Journal of Management, 23(1), 35-44.

Leavitt, H., (1989). Educating our MBAs: On teaching what we haven't taught. California Management Review, 31(3), 38-50.

Lin, T. \& Cheng, Y. (2010). Exploring the knowledge network of strategic alliance research: A cocitation analysis. International Journal of Electronic Business Management, 8(2), 152-160.

Macdonald, S. \& Kam, J. (2007). Ring a ring o' roses: Quality journals and gamesmanship in management studies. Journal of Management Studies, 44(4), 640-655.

Macdonald, S. \& Kam. J., (2007). Ring a Ring o' Roses: Quality Journals and Gamesmanship in Management Studies. Journal Management Studies, 44(4), 640-655.

McCain, K. (1990). Mapping authors in intellectual space: A technical overview. Journal of the American Society for Information Science, 41(6), 433-443.

McGrath, M. (2007). School bullying: tools for avoiding harm and liability. Thousand Oaks: Corwin Press.

McKelvey, B. (2006). Comment on Van De Ven and Johnson's 'Engaged Scholarship': Nice Try, But ... Academy of Management Review, 31(4), 822-829.

McTiernan, S. \& Flynn, P. M. (2011). "Perfect storm" on the horizon for women business school deans? Academy of Management Learning and Education, 10(2), 323-339.

Mintzberg, H. \& Gosling, J. (2002). Educating managers beyond borders. Academy of Management Learning and Education, 1(1), 64-76.

Mintzberg, H. (2004). Managers Not MBAs: A Hard Look at the Soft Practice of Managing and Management Development. San Francisco: Berrett-Koehler.

Morgeson, F. P., \& Nahrgang, J. D. (2008). Same as It Ever Was: Recognizing Stability in the Business Week Rankings. Academy of Management Learning and Education, 7(1), 26-41.

Navarro, P. (2006). The Well-Timed Strategy: Managing the Business Cycle for Competitive Advantage. Upper Saddle River: Wharton School Publishing.

Navarro, P. (2008). The MBA core curricula of top-ranked U.S. business schools: A study in failure? Academy of Management Learning and Education, 7(1), 108-123. 
BBR

17

474

Nicolai, A. \& Seidl, D. (2010), That's relevant! different forms of practical relevance in management science. Organization Studies, 31(9-10), 1257-1285.

Nowotny, H., Scott, P. \& Gibbons, M. (2001). Re-thinking science: Knowledge and the public in an age of uncertainty. Cambridge: Polity Press.

Ofori-Dankwa, J. \& Julian, S.D. (2005). From thought to theory to school: The role Of contextual factors in the evolution of schools of management thought. Organization Studies, 26 (9), 1307-1329.

O’Brien, J., Drnevich, P., Russell C. \& Armstrong, C. (2010). Does Business School research add economic value for students? Academy of Management Learning and Education, 9(4), 638-651.

Parnell, G., Bresnick, T., Tani, S. \& Johnson, E. (2012). Decision analysis soft skills, in Handbook of Decision Analysis, Hoboken: John Wiley and Sons, Inc.

Peng, M. \& Dess, G. (2010). In the spirit of scholarship. Academy of Management Learning and Education, 9(2), 282-98.

Peng, M. (2003). Institutional transitions and strategic choices. Academy of Management Review, 28(2), 275-296.

Petriglieri, G. \& Petriglieri, J. (2010). Identity Workspaces: The Case of Business Schools. Academy of Learning Education, 9(1), 44-60.

Petriglieri, G. \& Petriglieri, J. (2015). Can Business Schools Humanize Leadership? Academy of Learning Education, 14(4), 625-647.

Petriglieri, G., Wood, J. \& Petriglieri, J. (2011). Up Close and Personal: Building Foundations for Leaders' Development Through the Personalization of Management Learning. Academy of Management Learning and Education, 10(3), 430-450.

Pfeffer, J. \& Fong, C. (2004). The business school "business": some lessons from the US experience. Journal of Management Studies, 41(8), 1501-1520.

Pfeffer, J. (1993). Barriers to the Advance of Organizational Science: Paradigm Development as a Dependent Variable. Academy of Management Review, 18(4), 599-620.

Pfeffer, J. (2005). Why Do Bad Management Theories Persist? A Comment on Ghoshal. Academy of Learning and Education, 4(1), 96-100.

Porter, L. \& McKibbin, L. (1988). Management Education and Development: Drift or Thrust into the 21st Century? New York: McGrawHill.

Priem, L. R. \& Rosenstein, J. (2000). Is Organization Theory obvious to practitioners? A test of one established theory. Organization Science, 11(5), 509-522.

Ramos-Rodriguez, A., \& Ruiz-Navarro, J. (2004). Changes in the intellectual structure of strategic management research: A bibliometric study of the Strategic Management Journal, 1980-2000. Strategic Management Journal, 25(10), 981-1004.

Rindova, V., Williamson, I., \& Petkova, A. 2010. When is reputation an asset? Reflections on theory and methods in two studies of business schools. Journal of Management, 36(3), 610-619.

Rindova, V., Williamson, I., Petkova, A., \& Sever, J. (2005). Being good or being known: An empirical examination of the dimensions, antecedents, and consequences of organizational reputation. Academy of Management Journal, 48(6), 1033-1049. 
Romme, A., Avenier, M.-J., Denyer, D., Hodgkinson, G., Pandza, K., Starkey, K. \& Worren, N. (2015), Towards Common Ground and Trading Zones in Management Research and Practice. British Journal of Management, 26(3), 544-559.

Rousseau, D. \& McCarthy, S. (2007). Educating managers from an evidence-based perspective. Academy of Management Learning \& Education, 16(6), 84-101.

Rousseau, D. (2006). Is there such a thing as "evidence-based management"? Academy of Management Review, 31(2), 256-269.

Rubin, R. \& Dierdorff, E. (2009). How relevant is the MBA? Assessing the alignment of required curricula and required managerial competencies. Academy of Management Learning and Education, 8(2), 208-224.

Rubin, R. \& Dierdorff, E. (2011). On the road to Abilene: Time to manage agreement about MBA curricular relevance. Academy of Management Learning and Education, 10(1), 48-61.

Rutherford, S., Mann, M.E., Wahl, E. \& Ammann, C. (2012). Comment on: "Erroneous Model Field Representations in Multiple Pseudoproxy Studies: Corrections and Implications" by Jason E. Smerdon, Alexey Kaplan and Daniel E. Amrhein, Journal Climate, 26, 3482-3484.

Rynes, S., Bartunek, J. \& Daft, R. (2001). Across the Great Divide: Knowledge Creation and Transfer between Practitioners and Academics. Academy Management Journal, 44(2), 340-355.

Safón, V. (2007). Factors that influence recruiters' choice of b-schools and their MBA graduates: Evidence and implications for b-schools. Academy of Management Learning \& Education, 6(2), 217-233.

Sandberg, J. \& Tsoukas, H. (2011). Grasping the logic of practice: Theorizing through practical rationality. Academy of Management Review, 36(2), 338-360.

Sauder, M., \& Lancaster, R. (2006). Do rankings matter? The effects of U.S. News and World Report rankings on the admissions process of law schools. Law and Society Review, 40(1), 105-134.

Sauder, M., \& Lancaster, R. (2006). Do rankings matter? The effects of U.S. News and World Report rankings on the admissions process of law schools. Law and Society Review, 40(1), 105-134.

Scafuto, I., Serra, F., Mangini, E., Maccari, E. \& Ruas, R. (2017). The impact of flipped classroom in MBA's evaluation. Education + Training, 59, 914-928

Schoemaker, P. (2008), Rethinking management education: the future challenges of Business. California Management Review, 50(3), 119-39.

Serra, F., Ferreira, M. \& Almeida, M. (2013). Organizational decline: a yet largely neglected topic in organizational studies. Management Research: The Joumal of the Iberoamerican Academy of Management, 11(2), $133-156$.

Shrivastava, P., Ivanaj, S. \& Persson, S. (2013) Transdisciplinary Study of Sustainable Enterprise, Journal of the Business Strategy and the Environment, 22(4), 230-244.

Simon, H. (1967). The business school: A problem in organizational design. Journal of Management Studies, 4(1), 1-16.

Slater, D. J. \& Dixon-Fowler, H. R. (2010). The future of the planet in the hands of MBAs: An examination of CEO MBA education and corporate environmental Performance. Academy of Management Learning and Education, 9(3), 429-441.

Starkey, K. \& Madan, P. (2001). Bridging the Relevance Gap: Aligning Stakeholders in the future of management research. British Journal of Management, 12(SI), 3-26. 
BBR

17

476

Starkey, K. \& Tempest, S. (2009). The winter of our discontent: The design challenge for business schools. Academy of Management Learning and Education, 8(4), 576-586.

Starkey, K. \& Tiratsoo, N. (2007). The Business School and the Bottom Line. Cambridge: Cambridge University Press.

Starkey, K., Hatchuel, A. \& Tempest, S. (2004). Rethinking the Business School. Journal of Management Studies, 41(8), 1521-1531.

Stiles, D.R. (2004). Narcissus revisited: The values of management academics and their role in Business School strategies. UK and Canada: British Journal of Management, 15(2), 157-175.

Thomas, H. \& Wilson, A. (2011). Physics envy, cognitive legitimacy or practical relevance: dilemmas in the evolution of management research in the UK. British Journal of Management, 22(3), 443-456.

Tranfield, D. \& Starkey, K. (1998). The Nature, Social Organization and Promotion of Management Research: Towards Policy. British Journal of Management, 9(4), 341-353.

Trank, C. \& Rynes, S. (2003). Who moved our cheese? Reclaiming professionalism in business education. Academy of Management Learning and Education, 2(2), 189-205.

Trank, C. (2014). Reading evidence-based management: The possibilities of interpretation. Academy of Management Learning and Education, 13(3), 381-395.

Trieschmann, J., Dennis, A., Northcraft, G. \& Nieme Jr., A. (2000). Serving constituencies. In, Business Schools: M.B.A. program versus research performance. Academy of Management Journal, 43(6), $1130-1141$.

Tsui, A. (2013). The spirit of science and socially responsible scholarship. Management and Organization Review, 9(3), 375-394.

Tushman, M., Fenollosa, A., McGrath, D., O’Reilly, C. \& Kleinbaum, A. (2007). Relevance and rigor: Executive education as a lever in shaping practice and research. Academy of Management Learning and Education, 6(3), 345-365.

Vaara, E. \& Fay, E. (2011). How can a Bourdieusian perspective aid the analysis of MBA education? Academy of Management Learning and Education, 1(10), 27-39.

Vaara, E., \& Fay, E. (2012). Reproduction and change on the global scale: A Bourdieusian perspective on management education. Journal of Management Studies, 49(6), 1023-1051.

Van de Ven, A. (2007). Engaged Scholarship: A Guide for Organizational and Social Research. New York: Oxford University Press.

Van de Ven, A., \& Johnson, P. (2006). Knowledge for theory and practice. Academy of Management Review, 31, 802-821.

Vogel, R., \& Güttel, W. (2013). The dynamic capability view in strategic management: a bibliometric review. International Journal of Management Reviews, 15(4), 426-446.

Von Krogh, G., Rossi-Lamastra, C., \& Haefliger, S. (2012). Phenomenon-based research in management and organization science: When is it rigorous and does it matter? Long Range Planning, 45(4), 277-298.

Waddock, S. \& Lozano, J. (2013). Developing more holistic management education: Lessons learned from two programs. Academy of Management Learning and Education, 12(2), 265-284.

Walsh, M. (2012). Conceptualizing classroom interactional competence. Novitas-Royal Research on Youth and Language, 6(1), 1-14.

Walsh, S. (2011). Exploring Classroom Discourse: Language in Action. London: Routledge. 
Wasserman, S. \& Faust, K. (1994). Social Network Analysis Methods and Applications. Cambridge: Cambridge University Press.

Willmott, H. (2012). Reframing Relevance as 'Social Usefulness': A Comment on Hodgkinson and Starkey's 'Not Simply Returning to the Same Answer Over and Over Again'. British Journal of Management, 23(4), 598-604.

Wilson, D., \& McKiernan, P. (2011). Global mimicry: putting strategic choice back on the business school agenda. British Journal of Management, 22(3), 457-469.

Wood Jr., T., \& Cruz, J. (2014). MBAs: Cinco Discursos em Busca de uma Nova Narrativa. Cadernos EBAPE.BR, 12(1), 26-44.

Wright, R., Paroutis, S. \& Blettner, D. (2013). How useful are the strategic tools we teach in Business Schools? Journal of Management Studies, 50(1), 92-152.

Zupic, I., \& Čater, T. (2015). Bibliometric methods in management and organization. Organizational Research Methods, 18(3), 429-472.

\section{AUTHOR'S CONTRIBUTION}

All the authors contributed to the conception, design, acquisition, analysis and interpretation of data, as well as for the review of the final version of the work.

\section{CONFLICTS OF INTEREST}

The authors declare they have no conflict of interests regarding the article. 


\section{APPENDIX 1. BIBLIOMETRIC RESULTS}

17

\section{Co-citation analysis}

The factor analysis for the co-citation (Table A1.1) of the bibliographic coupling references enabled the identification of three factors responsible for $64.3 \%$ of the variance, the first factor being dominant. The named factors are: Factor CC1: Theory and Practice Gap; Factor CC2: Social Relevance; Factor CC3: Curricula and Practice. The works included in the co-citation are predominantly conceptual and in essays or books.

Table A1.1

Co-citation Factor Analysis results

\begin{tabular}{|c|c|c|c|}
\hline \multirow[b]{2}{*}{ References } & \multicolumn{3}{|c|}{ Factor loads } \\
\hline & $\begin{array}{c}\text { CC1 } \\
\text { Theory and Practice Gap }\end{array}$ & $\begin{array}{c}\text { CC2 } \\
\text { Social Relevance }\end{array}$ & $\begin{array}{c}\text { CC3 } \\
\text { Curricula and Practice }\end{array}$ \\
\hline Nowotny et al., 2001 &, 886 &, 056 &, 170 \\
\hline Anderson et al., 2001 &, 825 &, 103 &, 034 \\
\hline Tranfield \& Starkey, 1998 & ,823 &, 193 &,- 007 \\
\hline Gibbons et al., 1994 &, 821 &,- 088 &, 345 \\
\hline Grey, 2001 & ,806 &,- 113 & ,338 \\
\hline Pfeffer, 1993 & ,782 & ,106 &,- 109 \\
\hline Shapiro et al., 2007 & ,660 &,- 178 &, 585 \\
\hline Van de Ven \& Johnson, 2006 & ,657 & ,432 &,- 027 \\
\hline Starkey \& Madan, 2001 & 651 &, 274 & 034 \\
\hline Van de Vem, 2007 & ,635 & ,366 &, 044 \\
\hline Rousseau, 2006 &, 598 &, 562 & 072 \\
\hline Hambrick, 1994 &, 584 & 390 & ,399 \\
\hline Kuhn, 1962 &, 514 &, 310 & ,469 \\
\hline Leavitt, 1989 & ,492 &, 484 & ,427 \\
\hline Ghoshal, 2005 &, 195 &, 840 &, 114 \\
\hline Adler \& Harzing, 2009 &, 061 &, 824 & ,226 \\
\hline Ferraro et al., 2005 &, 251 & ,791 & ,207 \\
\hline Bennis \& O’Toole, 2005 &, 194 & ,755 &,- 059 \\
\hline Gioia \& Corley, 2002 & ,076 &, 729 & ,477 \\
\hline Cheit, 1985 &, 023 & ,716 & ,159 \\
\hline Starkey \& Tiratsoo, 2007 & ,406 & ,664 &, 064 \\
\hline Datar et al., 2010 &, 031 & ,647 &, 221 \\
\hline Friga et al., 2003 &, 101 & ,641 &, 285 \\
\hline Porter \& McKibbin, 1988 & ,445 & ,613 &, 221 \\
\hline Gordon \& Howell, 1958 & ,213 &, 579 &, 522 \\
\hline Navarro, 2008 &,- 138 &, 528 & ,386 \\
\hline Pfeffer \& Fong, 2002 & ,256 &, 152 & ,892 \\
\hline Pfeffer \& Sutton, 2007 &, 321 & 035 &, 880 \\
\hline Pfeffer \& Fong, 2004 &, 125 & ,364 &, 845 \\
\hline Starkey \& Tempest, 2009 &,- 108 & 044 & ,777 \\
\hline
\end{tabular}


Table A1.1

Cont.

\begin{tabular}{lccc}
\hline \multirow{2}{*}{ References } & \multicolumn{3}{c}{ Factor loads } \\
\cline { 2 - 4 } & CC1 & $\begin{array}{c}\text { CC2 } \\
\text { Social Relevance }\end{array}$ & $\begin{array}{c}\text { CC3 } \\
\text { Curricula and Practice }\end{array}$ \\
\hline Rubin \& Dierdorff, 2009 &,- 174 &, 189 &, 708 \\
Mintzberg \& Gosling, 2002 &, 501 &, 201 &, 651 \\
Trieschmann et al., 2000 &, 019 &, 137 &, 619 \\
Mintzberg, 2004 &, 316 &, 412 &, 607 \\
Khurana, 2007 &, 242 &, 451 &, 591 \\
Starkey et al., 2004 &,- 012 &, 410 &, 579 \\
Rynes et al., 2001 &, 374 &, 118 &, 556 \\
Rousseau \& McCarthy, 2007 &, 120 &, 345 &, 496 \\
\hline
\end{tabular}

Note: The complete references are available at https://rive.google.com/file/d/1iFNj0bRD1znifs6z1d4VRM2ea9 $\mathrm{CmoFb} /$ view? usp=sharing.

Source: Elaborated by the authors.

To select the number of articles, presented in Table A1.1, we used Lotka's law of bibliometrics in the citation analysis (File link: https://drive.google.com/file/d/1ed7BUQw0F11E6GJIQUc_ 9IAyR38BjmO_/view?usp=sharing). It indicates that a relatively small number of cited articles (around 5\%) would be representative of the intellectual structure that influences the theme (Nath \& Jackson, 1991). The selected sample of 44 references was reduced to 38 due to adjustments during the factor analysis procedure. The articles of the sample selected, presented in Table I.1 in the Supplementary File at the previous link, correspond to 603 citations in 6200 citations in the 76 articles referenced (approximately 10\% of the citations).

The bibliographic co-citation network in Figure A1.1 shows the links between the articles in the sample. Table A.1.2 shows the explained variance from the factor analysis and the density and cohesion of each of the factors identified in the network.

Factor CC1 was labeled "Theory and Practice Gap". It contains 14 works. The articles show a high density in the network, suggesting that the references are predominantly shared in the same factor (Figure A1.1). The low cohesion indicates that this factor connects with the others (Table A1.2).

Factor CC2, named "Social Relevance" is represented by 12 works (Table A1.1). This factor shows a relatively high density between the works. The references are predominantly shared in the same factor, with a relatively homogeneous body (Figure A1.1). The low cohesion indicates that this factor connects with the others (Table A1.2).

We labeled Factor CC3 as "Curricula and Practice". This factor is made up of 12 articles that generally criticize the curricula and content of teaching at B-Schools (Table A1.1). The articles showed a relatively heterogeneous body of literature (Figure A1.1) by the relatively low-density measure (Table A1.2). The low cohesion indicates the connection of this factor with others. 
BBR

17

480

Figure A1.1. Co-citation network.

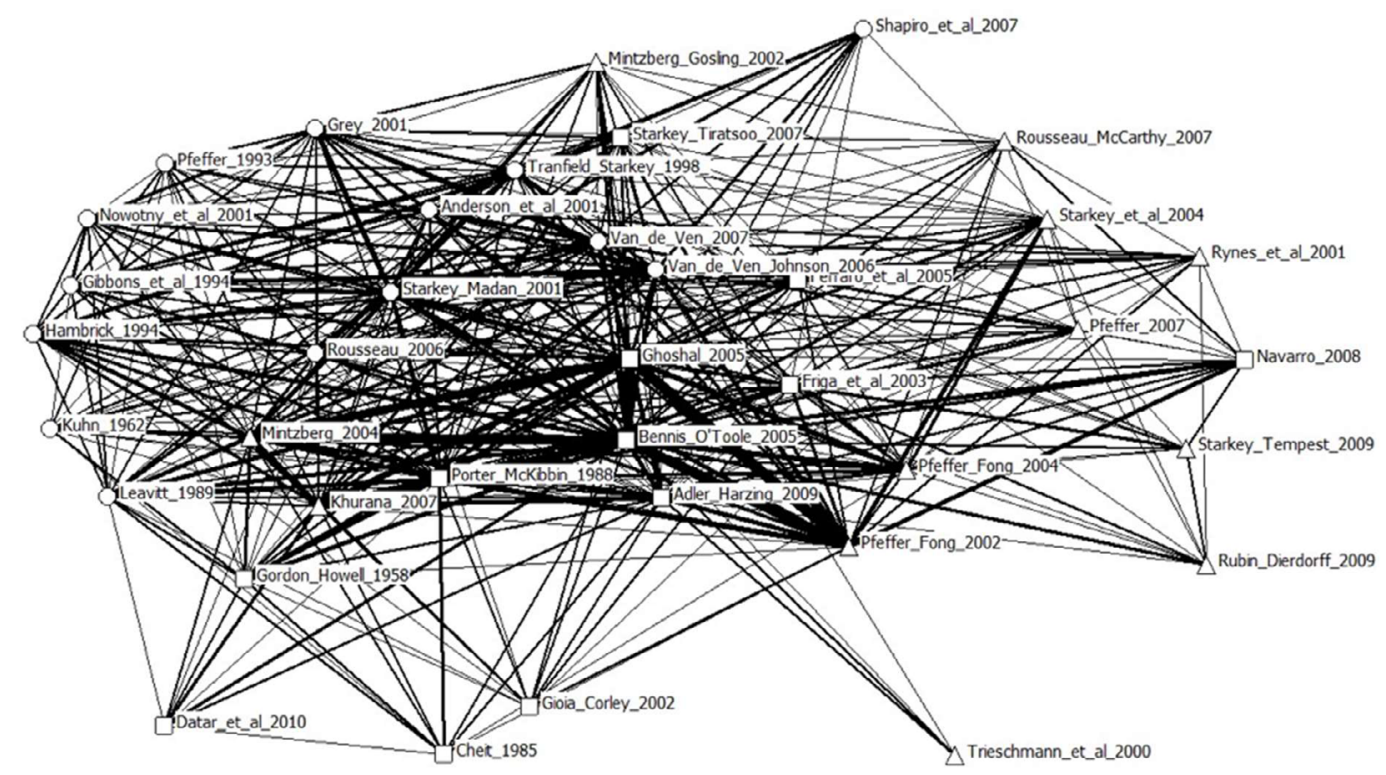

Legend:

OFactor 1; $\square$ Factor 2; $\triangle$ Factor 3.

Source: Elaborated by the authors.

Table A1.2

Co-citation factor analysis and network metrics

\begin{tabular}{cccccccc}
\hline Co-citation & Works & Density & Cohesion & $\begin{array}{c}\text { \% Variance } \\
\text { explained }\end{array}$ & $\begin{array}{c}\text { \% Variance } \\
\text { accumulated }\end{array}$ & KMO & Bartlett \\
\hline CC1 & 14 & 0.85 & 1.58 & 40.94 & 40.94 & & \\
CC2 & 12 & 0.71 & 1.16 & 13.02 & 53.96 & & \\
CC3 & 12 & 0.41 & 0.79 & 10.34 & 64.30 & & 0.48 \\
\hline Total & 38 & & & & & 0.000 \\
\hline
\end{tabular}

Source: Elaborated by the authors. 
The 6 factors were identified (Table A1.3). The bibliographic coupling network in Figure A1.2 shows the nodes, which are the articles in the sample, and the lines, which represent their shared references. The network shows two clusters, one formed by Factor BC2 and the second formed by Factors BC1, BC3, BC4, BC5 and BC6. Then, assuming that a logical order was observed in the network, it is possible to infer that Factor BC1 - "B-School Relevance", and Factor BC3 "Relevance to practice", are the central factors of the discussion, as they are related to the other factors and clearly have greater density. These are the factors from the factor analysis with the most articles. These factors are linked to the challenges facing B-Schools in regards to the market and the relevance of their research, respectively. Another aspect that justifies these factors being the most central is that they include the three articles with the highest degree of centrality. This means that they are coupled with many articles and have points in common with them, meaning their approaches are predominant in the network. In Factor BC1, there are two articles with a high degree of centrality. The first is Petriglieri and Petriglieri (2015), with 282 couplings, in which the authors address the teaching of leadership in B-Schools. The second is that of McTiernan and Flynn (2011), with 281 couplings, in which the authors address the criticisms of B-Schools from the perspective of their deans and their personal characteristics. Factor BC3 contains the article by Hughes et al., (2011), with the highest centrality of the three, with 286 couplings.

Due to the centrality of Factors BC1 and BC3, it is perceived that they communicate with the other factors, providing support for the other discussions. It is connected with Factor BC4 - "Curricula Relevance", which is linked to Factor BC2 - Teaching Relevance, and Factor BC6 - Reputation - its characteristics and influences. Meanwhile, in Factors BC1, BC3 and BC5 - "B-Schools evolution and influence", the authors base their discussions on the evolution of B-Schools. The way in which B-Schools evolved distanced them from the needs of the market and society. Schools are under pressure to conduct research that is more theoretical, which has little bearing on everyday phenomena and the reality that company managers deal with in practice. This has led to questions being raised with regard to this research and its relationship with the teaching of management, which is addressed in Factor BC2. This relationship is intermediated by the preparation of students for the market. Thus, the criticism is that if B-Schools claim to prepare students for the market, which is, or should be, their main goal, why are they conducting research that is not in keeping with this proposal? It has resulted in a reputation crisis, which is discussed by a significant number of authors, especially in Factor BC 6.

Factor BC1 has the highest number of articles, with 28 (Table A1.3). We labeled it as "B-School Relevance". The factor has the highest explained variance with $25.48 \%$ (Table A1.4) representing the predominance of the stream. The factor shows a homogeneous body of literature, considering the high-density measures. The relatively low cohesion (Table A1.4) and the cross loadings (Table A1.3) indicate the connection of this factor with others (Figure A1.2).

Factor BC3 has the second highest number of articles, with 18 (Table A1.3). This factor was named "Relevance to practice". This factor, contrary to Factor BC1, has the predominance of BJM, with 7 articles (Table A1.3). However, just two AMLE articles are present in Factor C33. This factor has an explained variance of $8.27 \%$ (Table A1.4). The factor shows a homogeneous body of literature focusing on the academic-practitioner divide. Considering the high-density measures, the relative low cohesion (Table A1.4) and the cross loadings (Table A1.3) indicate the connection of this factor to others (Figure A1.2). 
BBR

17

482

Factor BC4 has only 4 articles (Table A1.3), and we found it adequate to label it "Curricula Relevance". The factor has a low explained variance with 5.17\% (Table A1.4). Factor BC5, with 6 articles (Table A1.3), was identified as "B-School evolution and influence". The factor has a low explained variance with $3.89 \%$ (Table A1.4).

Factor BC6 has 5 articles (Table A1.3) and is named "Reputation". This factor is related to factor BC1 and presents some positive evidence of the relevance of B-Schools. It has the lowest explained variance with $2.98 \%$ (Table A1.4) and shows a homogeneous body of literature (Figure A1.2), considering the high-density measures. The relative low cohesion (Table A1.4) and the cross loadings (Table A1.3) also indicate the connection of this factor with others.

Factor BC2 has a high number of articles (15) (Table A1.3) and was named "Teaching Relevance". The bibliographic coupling network shows that Factor BC2 is more isolated in the right-hand corner of Figure A1.2. This is justified because the factor discusses how management is taught and, it focuses more on teaching tools and methodologies. This factor considers aspects regarding criticism of the teaching of management and the methodologies employed. The central discussion is always the same: that B-Schools evolved in such a way that the research they conduct is not very relevant to the market, even though they propose to prepare students for the challenges they will face in their careers.

In the other factors, especially on the left side of the network, which begins with the central factors (1 and 3), the authors show concern over how to ally theory and practice. in the classrooms of B-Schools. On the right side of Figure A1.2, the need for B-Schools to draw closer to companies is discussed in factor $\mathrm{BC} 2$.

Figure A1.2. Bibliometric coupling network diagram.

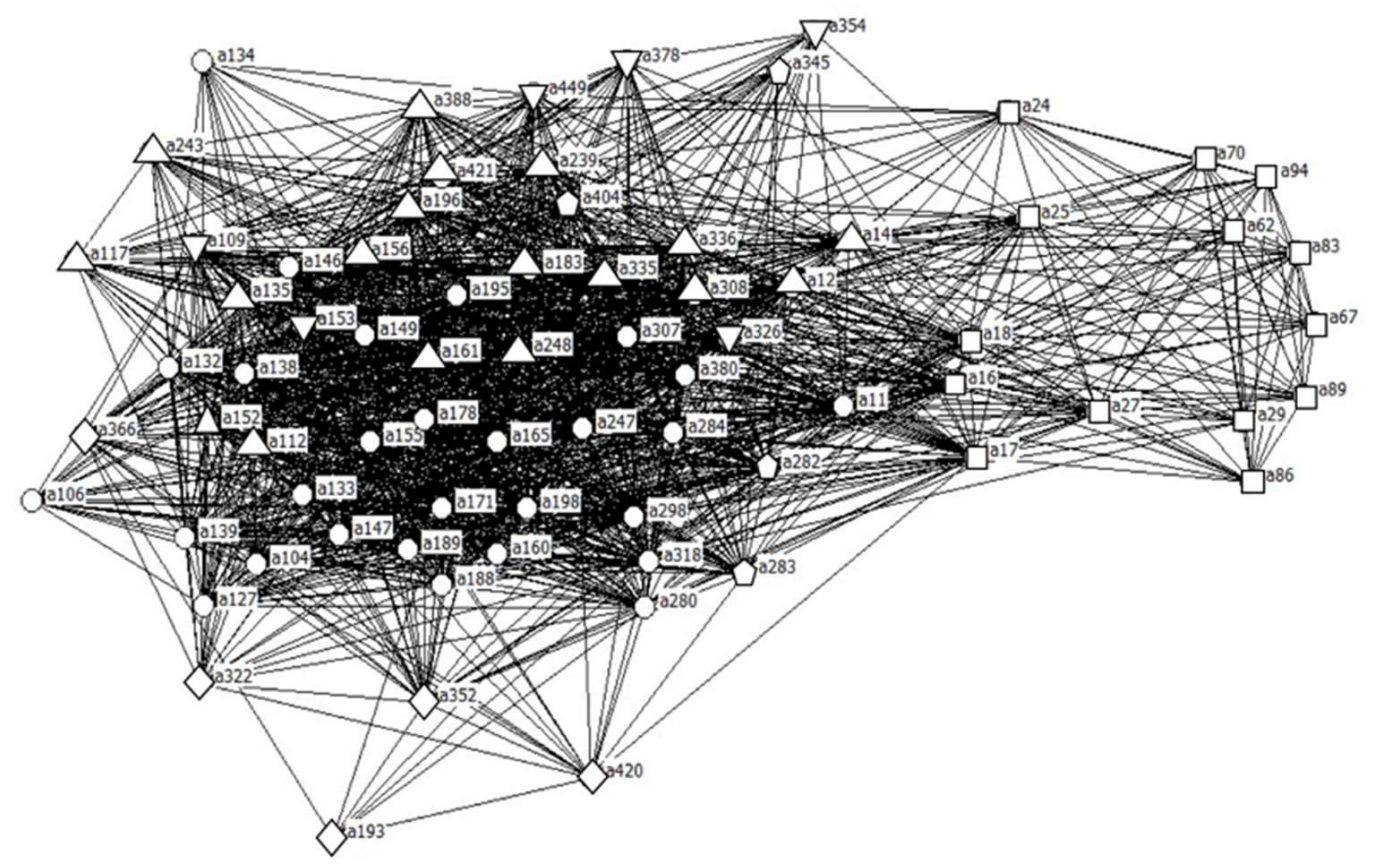

Legend:

○Factor $1 ; \square$ Factor $2 ; \triangle$ Factor $3 ; \triangle$ Factor $4 ; \nabla$ Factor $5 ; \diamond$ Factor 6.

Source: Elaborated by the authors. 


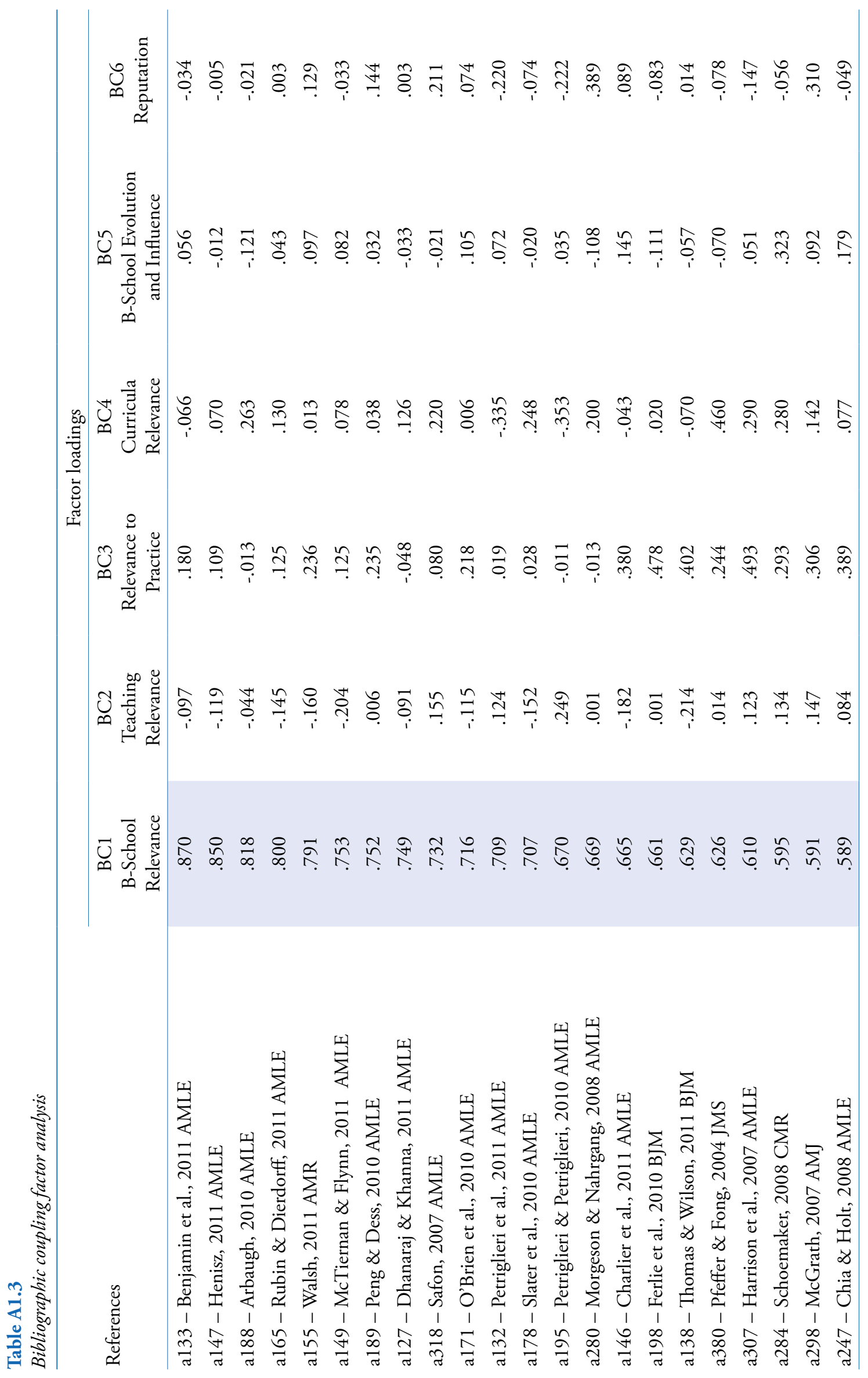


BBR

17

484

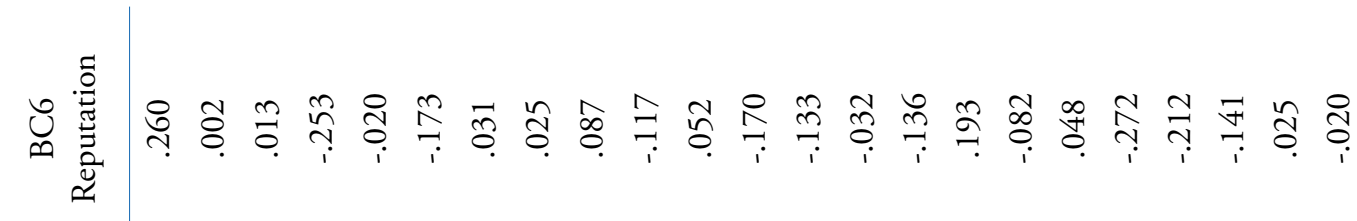

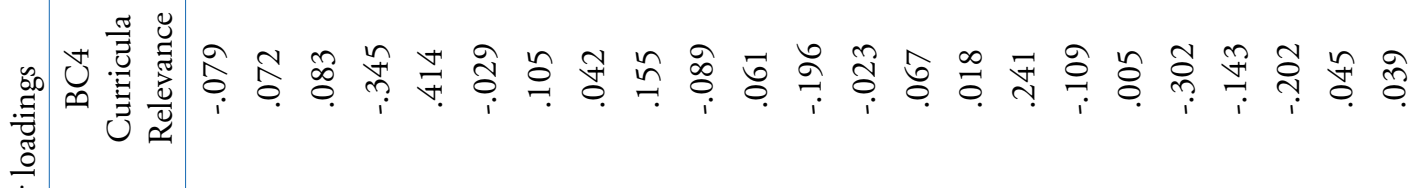

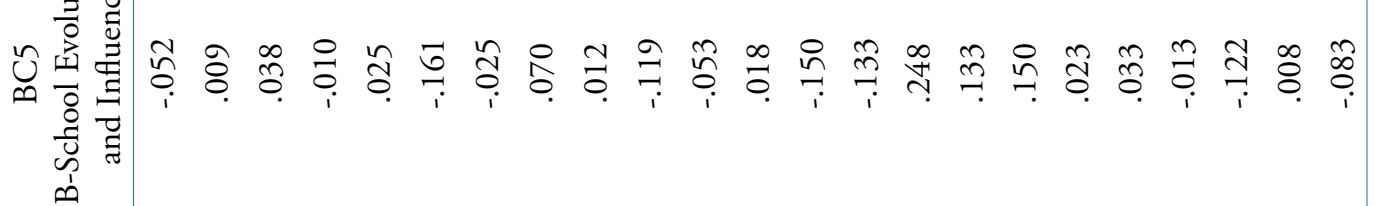

节

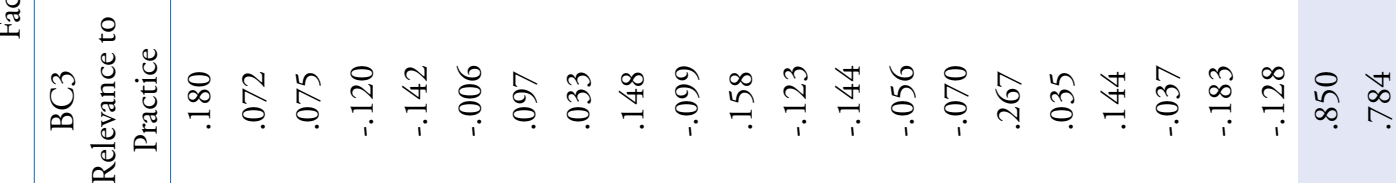

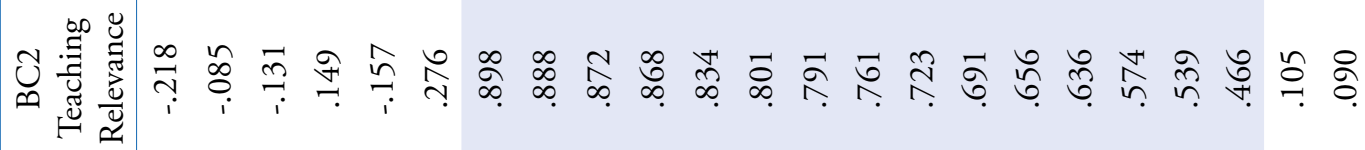

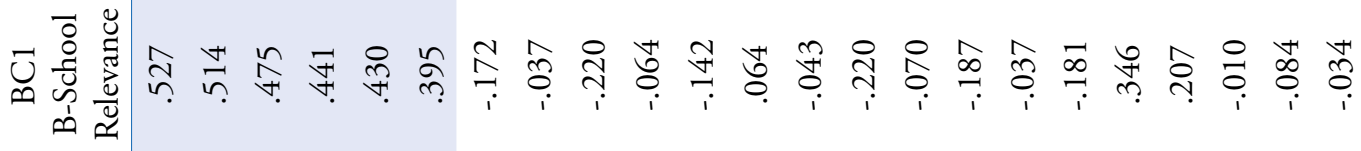

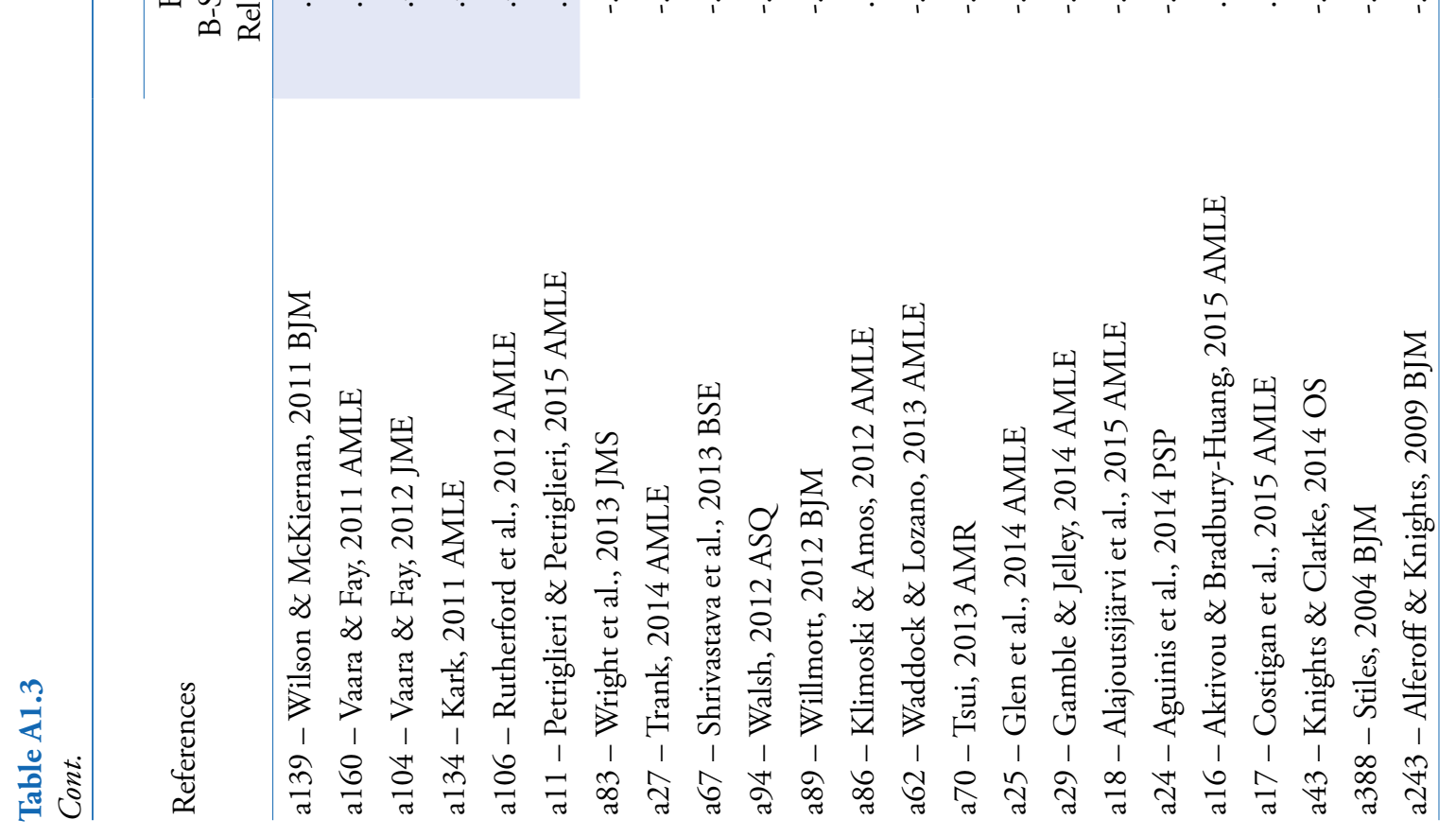




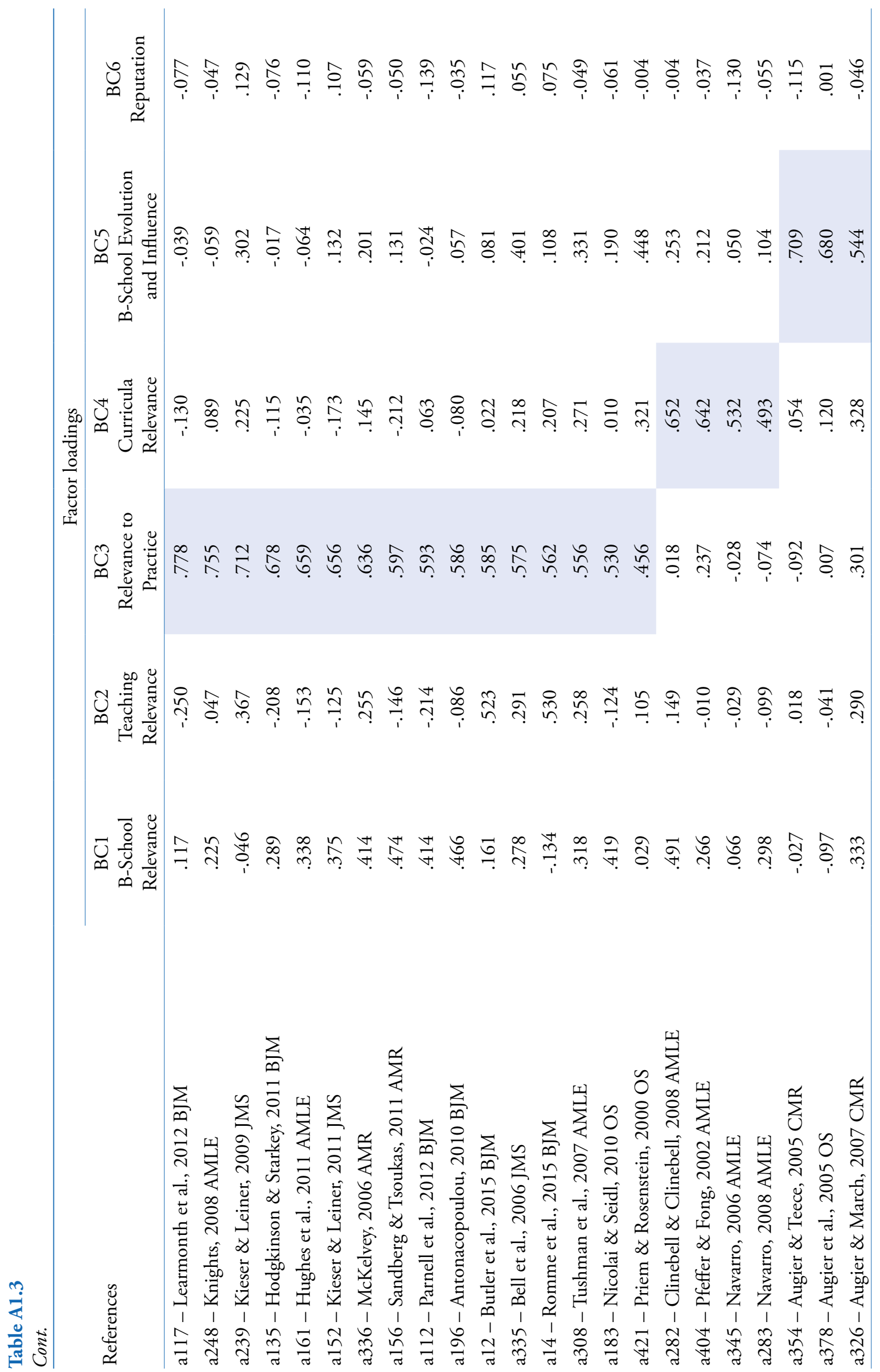




\section{BBR \\ 17 \\ 486}

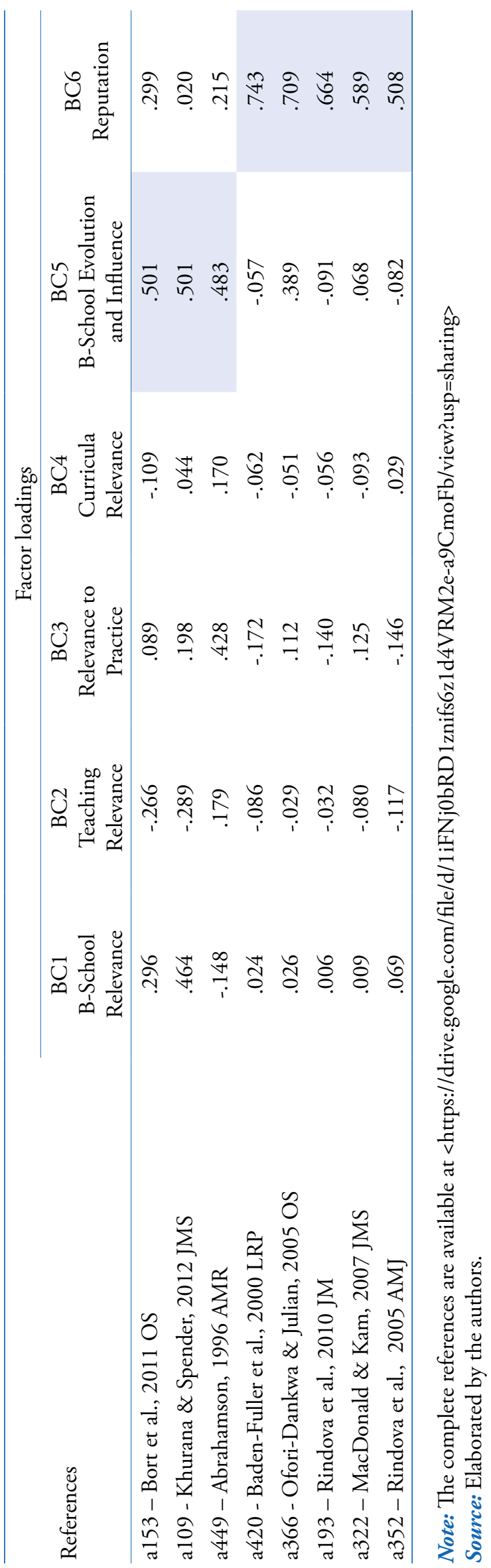

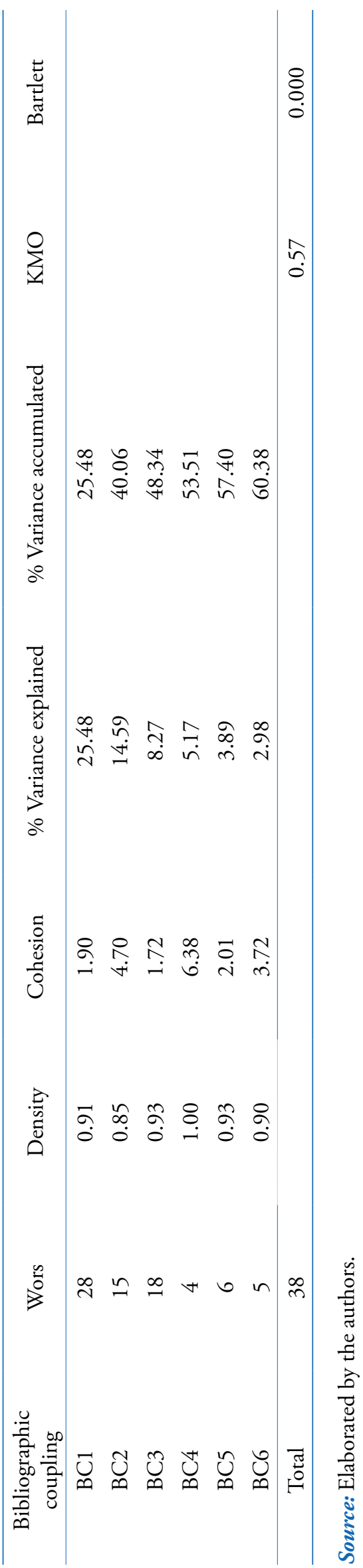


To build the intra-factor relations, we interpreted the cross-factor loadings from the factor analysis, the network shape and its metrics, as well as the reading of the articles. To support our readings regarding the relation of the co-citation factors, with the bibliographic coupling factors we calculated the sharing of references from the co-citation factors in the articles of the bibliographic coupling factors. The results are presented in Table A1.5 and Figure A1.3. In Table A1.5, the darker the cell, the greater is the relation between the co-citation and coupling factors. These results enabled us to integrate the co-citation and the bibliographic coupling. Together with the cross-loadings and network metrics enabled us to prepare Figure 1 that oriented our review.

Table A1.5

Influence of the co-citation factors references values on the bibliographic coupling factors

\begin{tabular}{ccccc}
\hline \multirow{3}{*}{ Factor } & & \multicolumn{3}{c}{ Cocitação } \\
\cline { 3 - 5 } & & CC1 & CC2 & CC3 \\
\hline \multirow{6}{*}{ Pairing } & BC1 & 7 & 26 & 37 \\
& BC2 & 8 & 24 & 25 \\
& BC3 & 45 & 14 & 18 \\
& BC4 & 5 & 23 & 5 \\
& BC5 & 8 & 18 & 7 \\
& BC6 & 4 & 2 & 6 \\
\hline
\end{tabular}

Source: Elaborated by the authors.

Figure A1.3.- Influence of the co-citation factors references graphic on the bibliographic coupling factors.

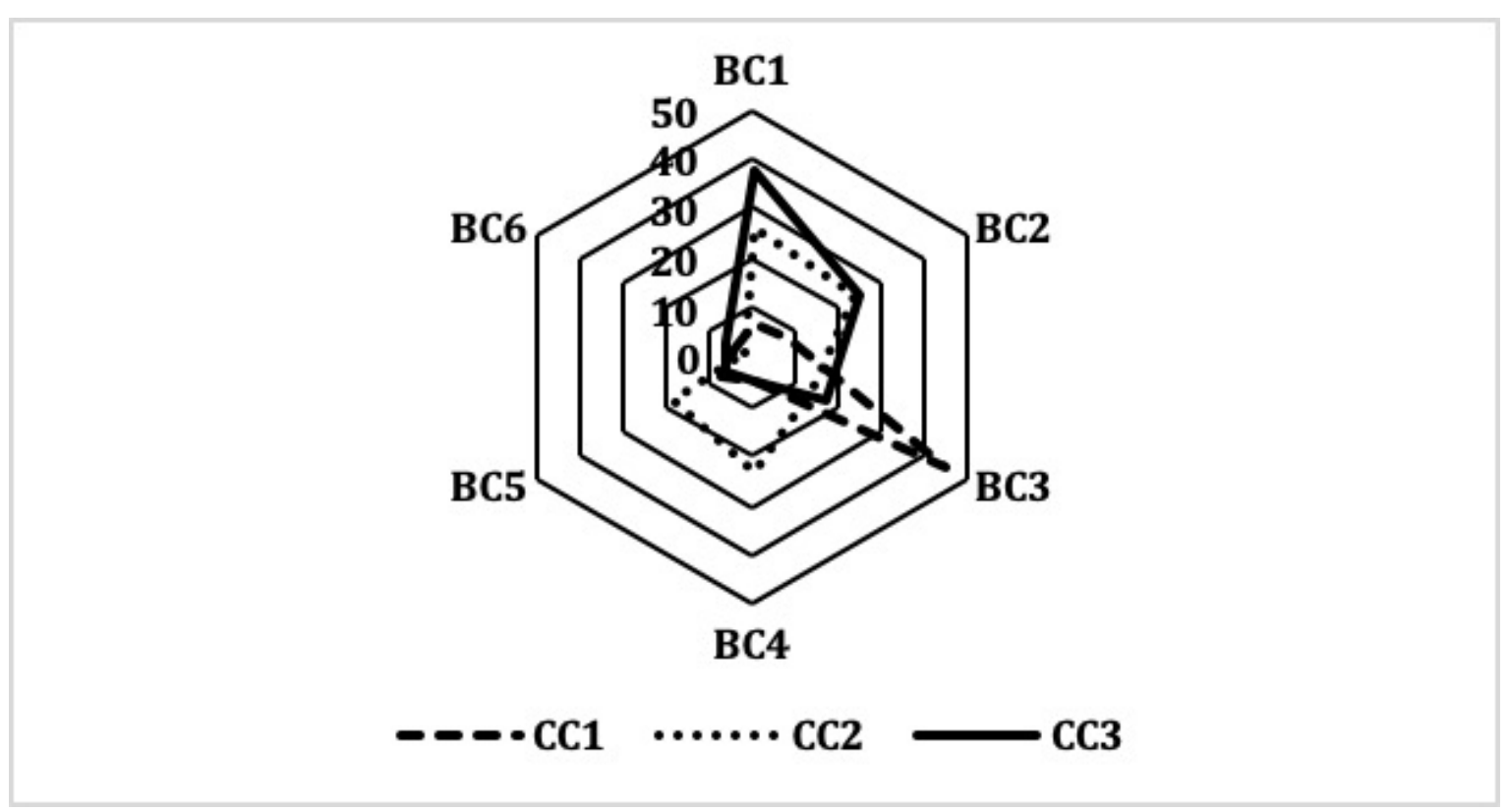

Source: Elaborated by the authors. 